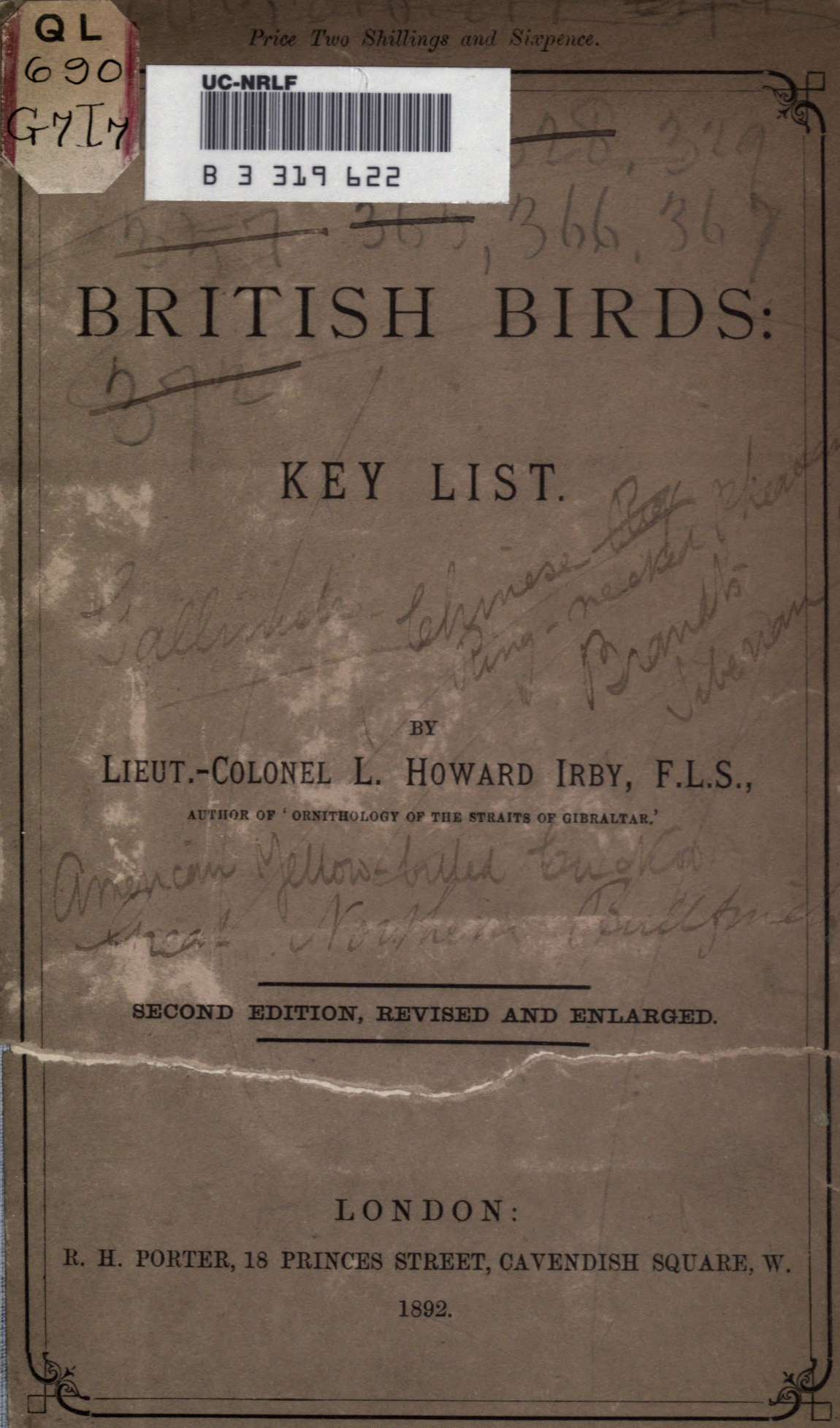




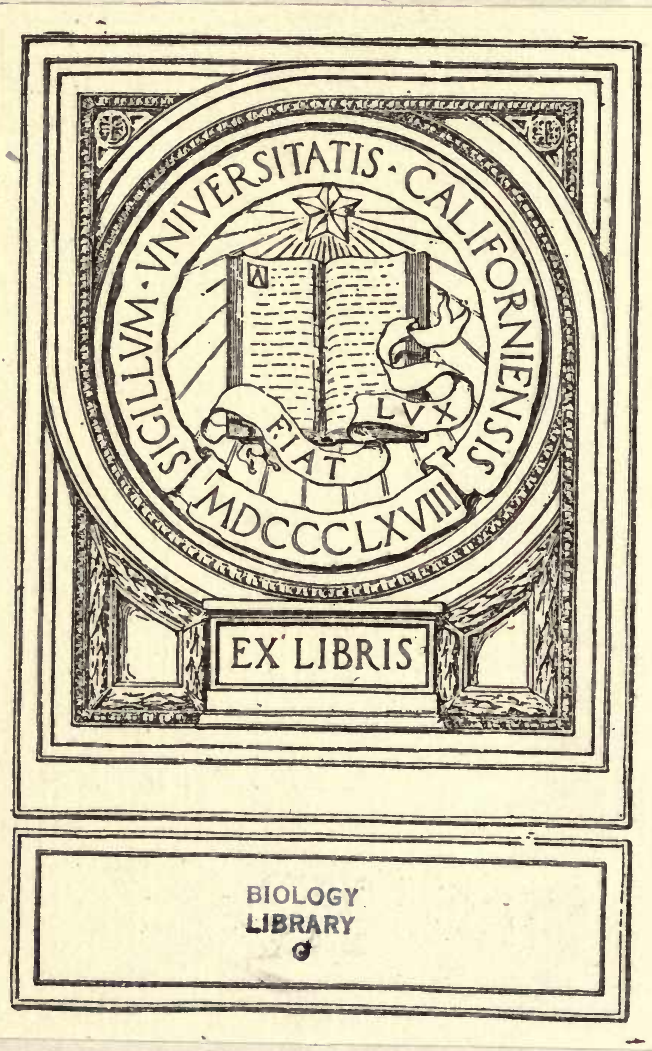






\title{
BRITISH BIRDS:
}

\section{KEY LIST.}

BY

\begin{abstract}
LIEUT.-COLONEL L. HOWARD /IRBY, F.L.S., ACTHOB OF 'ORNITHOLOGY OF TUE STRAITS OF GIBRALTAR.'
\end{abstract}

SECOND EDITION, REVISED AND ENLARGHI, :

\section{O N D N :}

R. H. PORTER, 18 PRINCES STREET, CAVENDISH SQTARE, W. 1892. 


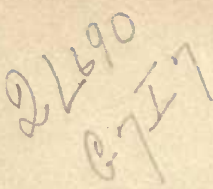

BIOLOGY

LIBRARY

G

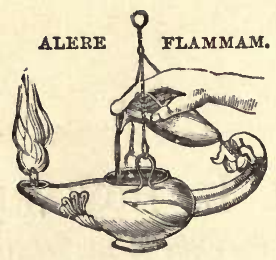

PRINTED BY TAYLOR AND FRANCTS, RED LION COURT, FLEET STREET.

$\because \because \because \quad: \because \vdots \vdots \because \vdots \vdots \vdots$

$\therefore: \vdots: \because: \because \because \vdots \vdots \vdots \vdots: \cdots \cdots$ 


\section{N TRO D UCTION.}

THIs attempt at a "Key List" of British Birds is not intended for scientific ornithologists, but for those who have only a slight knowledge of birds, so as to enable them to determine a species without having to search through bulky volumes.

Of course, such a list must be, to a great extent (as all Natural History works are), a compilation; but the writer has examined and compared specimens of all the species.

Every endeavour has been made to avoid technical and scientific terms and to be as concise as possible.

American land-birds included in "British" lists have been omitted; others might with propriety be struck out-sucb as specimens escaped from captivity, or included without sufficient inquiry as to their authenticity.

With slight modifications, the nomenclature and arrangement of the 'Ibis' List have been followed.

Measurements of length are given, but only as an attempt to show the proportionate size of a species. In the writer's opinion measurements are not of much service, especially as hardly any two persons measure a bird in the same manner.

Unless otherwise stated, the sexes are alike in plumage, and the remarks refer to adults in summer plumage.

A species is called "resident" when it is found in the country throughout the year, but there is no doubt that even among residents there is a partial migration.

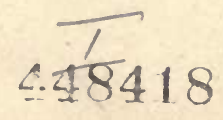


From "spring to autumn" signifies that the species is a regular migrant and breeds in some parts of the British Islands.

Habitat or geographical range of the rarer birds is given in the margin.

Of the 376 species included in this list some 132 are residents : about 52 are migrants, which breed, or have bred, in the British Islands; some of these, such as Chiffchaff, Quail, Land-Rail, \&c., rarely remain throughout the winter,-making the number of nesting species about 184 .

Regular winter visitors number about 37.

Northern stragglers number 23.

American stragglers are 23 in number.

The remainder are stragglers from the South and East, many having only occurred once.

Diagrams are given showing the names of the different parts of a bird. 

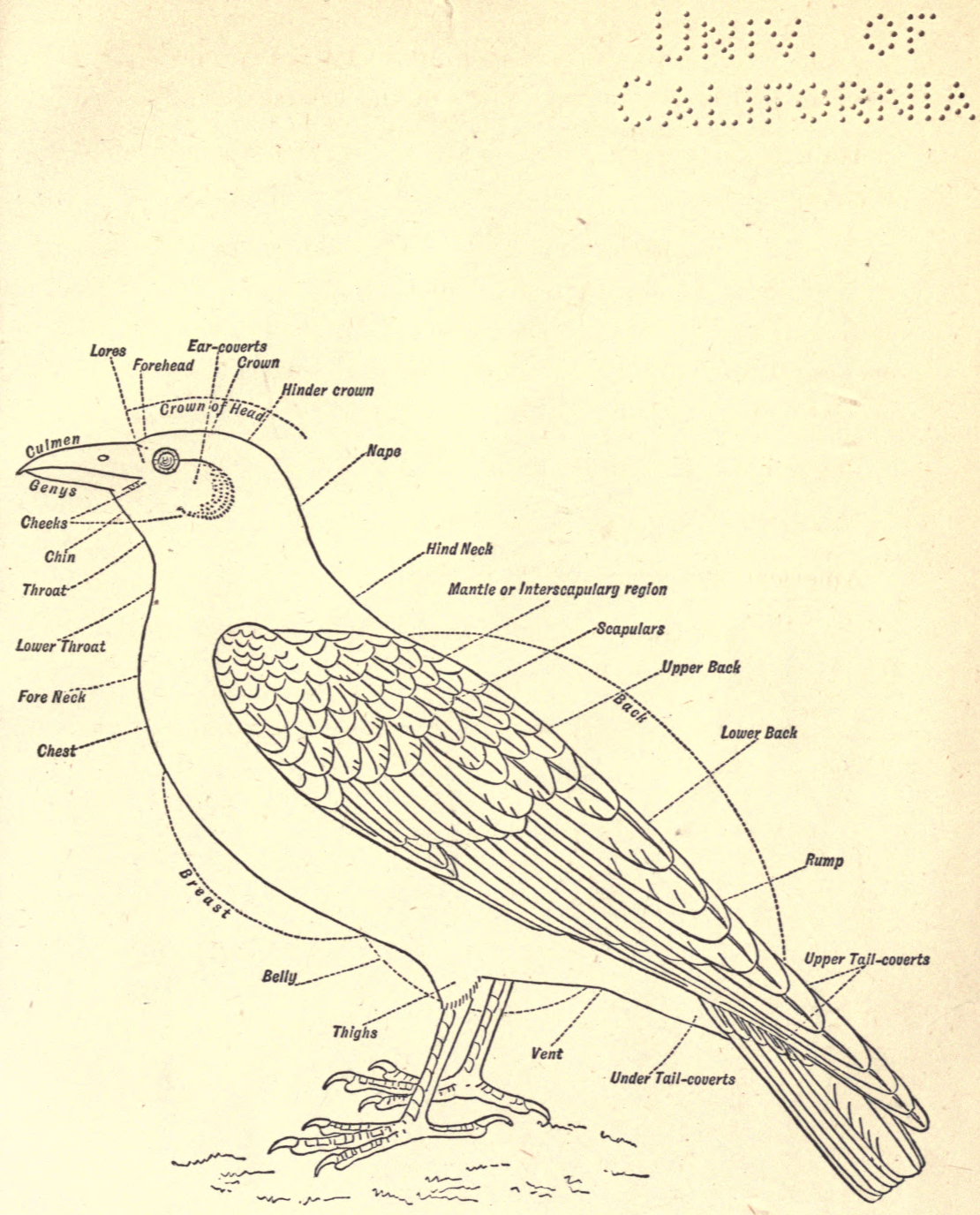



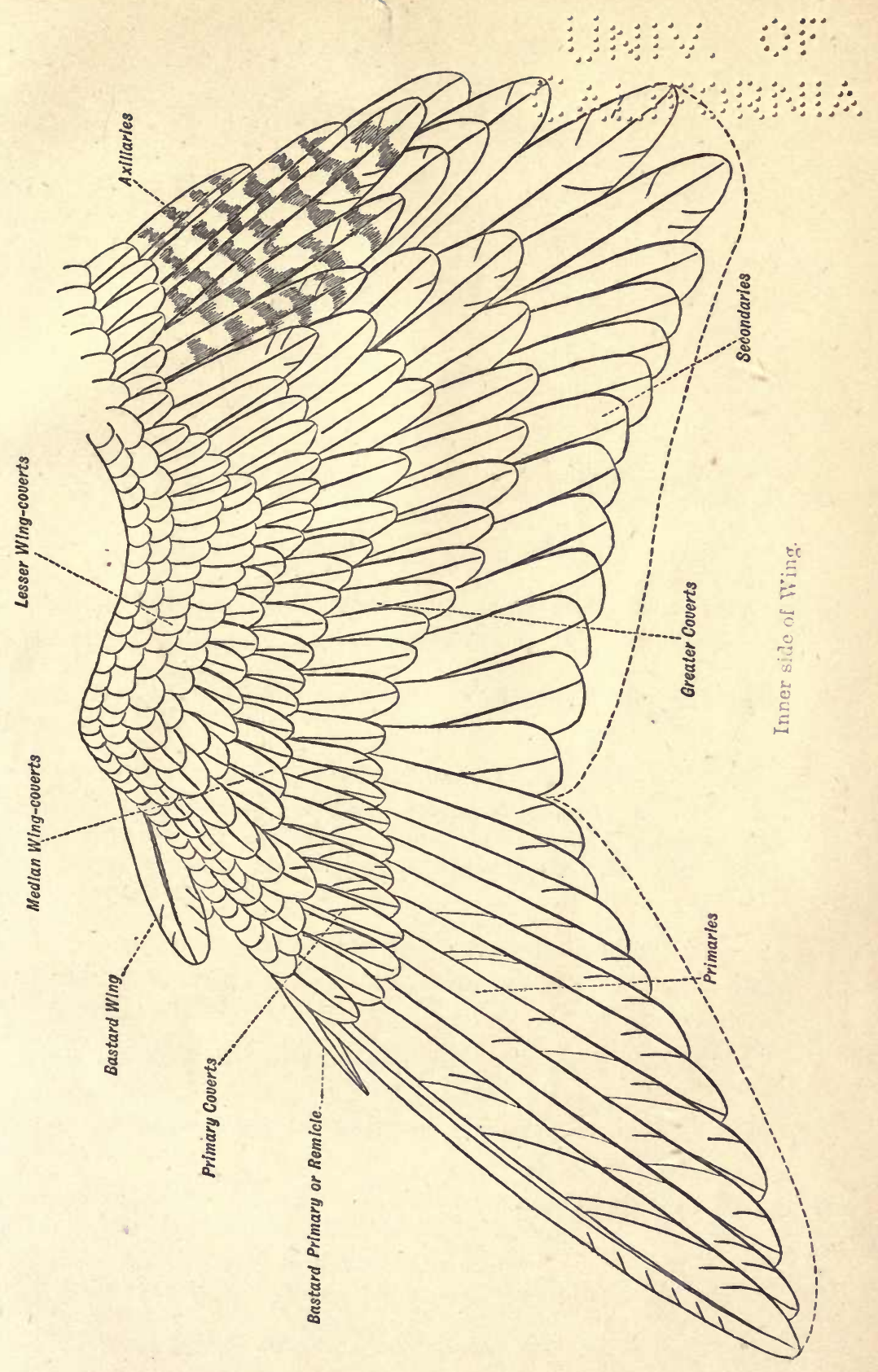




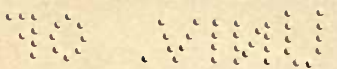

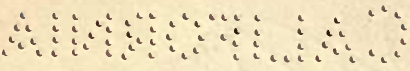


KEY LIS'I

OF

\section{BRITISH BIRDS.}

\section{Order PASSERES. Family TURDID在.}

Subfamily TURDINE. Young spotted.

1. Mistle-Thresh. Turdus viscivorus, Linnæus. Resident *.

Axillaries white; a white patch on end of inner web of two outer tailfeathers on each side.

Young. Spotted with buff and black on head and back. Length 11 inches.

2. Sorg-Throsh. Turdus musicus, Linnæus. Resident.

Axillaries buffish yellow; eye-stripe scarcely developed.

Young. Spotted; the feathers of upper surface with pale centres. After first moult young resembles adult, but has pale ends to the wingcoverts. Length 9 inches.

3. Redwirg. Turdus iliacus, Linnæus. Autumn to spring.

Axillaries chestnut-red; well-defined whitish streak over eye, reaching to nape. Length $8 \frac{3}{4}$ inches.

4. Fieldfare. Turdus pilaris, Linnæus. Autumn to spring.

43 Axillaries white; rump slate-grey. Length 10 inches.

Note.-Neither Redwings nor Fieldfares have yet been proved to brecd in the British Isles.

5. Black-throated Throsh. Turdus atrigularis, Temminck. Two N. Asia, bccurrences : Sussex, 1868, and Perthshire, 1879.

Axillaries grey, with a shade of chestnut.

Adult male. Throat and breast black; belly whitish; back greyish brown.

Female. Throat white, streaked and spotted with black. Length $9 \frac{1}{2}$ inches.

* See remarks on "Residents" in the Introduction. wintering in S. Asia. 
(n)

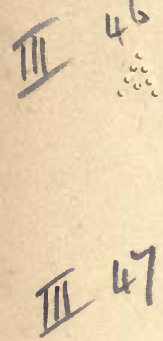

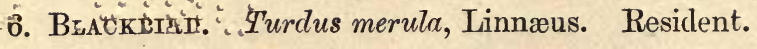

Riale. Blick : bill orange-yellow.

Peinate. Brounish black or reddish brown : bill brown.

Young. Like female, but more spotted; the male with blackish bill. Length 10 inches.

7. Ring-Ovzer. Turdus torquatus, Linnæus. Spring to autumn*; breeding in billy districts; occasionally remaining throughout the year.

Male. Uniform brownish black, with white crescent on chest.

Female. Lighter; crescent narrower, washed with brown.

Young. Spotted. Length 11 inches.

E. Asia.

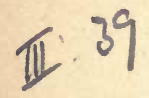

8. White's Thrush. Geocichla varia (Pallas). Rare winter straggler.

General colour above olive-brown, each feather with a crescent-shaped black band across the end. Axillaries with the basal half white, rest black; white band across the underpart of the wing. Fourteen tailfeathers. Length $12 \frac{1}{2}$ inches.

N. Asia, wintering in S. Asia, Java, and Sumatra.

II. $4^{5}$

S. Europe, wintering in Africa.
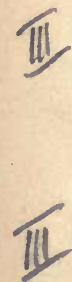

C. Asia, N.E. Africa, passing $\mathrm{S}$. in winter.

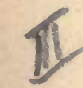

[Siberian Thrush. Geocichla sibirica (Pallas). One specimen, said to be from Surrey, 1860 (F. Bond).

Axillaries white, with slaty-grey tips. Tail of twelve feathers.

Male. General colour slate-grey; with conspicuous white eye-stripe reaching to nape.

Female. General colour above olive-brown; below with brown curved marks; eye-stripe buff. Length 9 inches.]

9. Rock-Thrush. Monticola saxatilis (Linnæus). One occurrence: Herts, 1843.

Tail chestnut, two centre feathers darker than others; axillaries and lower parts chestnut.

Male. Head and neck blue; centre of back nearly white.

Female. Brown, mottled. Length $7 \frac{1}{2}$ inches.

10. Wheatear. Saxicola onanthe, Linnæus. Spring to autumn.

Axillaries white, with dark centres.

Male. Above pale slate-grey; below white; ear-coverts black.

Female. Above dull brown; below buff; ear-coverts dark brown.

Young. Like the female, but spotted with dark markings on feathers above and below.

Both sexes in autumn are alike, resembling female in spring, but have buff margins to all the feathers.

(Rump white, as with all the Wheatears in this list.)

11. Isabeluine Wheateatr. Saxicola isabellina, Rüppell. Once: Nov. 1887, Cumberland.

Sexes alike, above sandy or dull brown, somewhat like the female of S. cenanthe. Axillaries and under wing-coverts white. Terminal half of tail black, rest white: the two centre feathers with more black than the others.

* "Spring to autumn," see remarks in the Introduction. 
12. Desert Wheatear. Saxicola deserti, Rüppell. Two occurrences: Scotland, Nov. 1880 ; Yorkshire, Oct. 1885.

N.E. Africa, S.W. Asia. tips.

Terminal half of tail black, rest white; axillaries black, with white

Male. Back, crown, and scapulars uniform buff; chin and throat black. Length $5 \frac{1}{2}$ inches.

13. Western Black-throated Wheatear. Saxicola stapazina, 3 Vieillot. One occurrence in Lancashire, May 1875.

Axillaries black; two-thirds of two centre tail-feathers black with the basal third white, the others white tipped with black.

Male. Crown, back, rump, breast, and belly white, suffused with buff on back and breast. Chin and upper throat black. Length $5 \frac{1}{2}$ inches.

14. Whivchat. Pratincola rubetra (Linnæus). Spring to autumn.

Male. Chest orange-rufous; white line over eye from bill to nape; basal half of tail white, rest black.

Female. Like male, but paler.

Young. Like old female, but more spotted, with white tips to the feathers. Length 5 inches.

15. Stonechat. Pratincola mubicola (Linnæus). Resident.

Male. Head, chin, and throat black; breast orange-chestnut; upper tail-coverts whitish, spotted with black. Tail blackish brown; outer web of outside feathers edged with buff.

Female. Upper tail-coverts reddish brown; lower parts rufous.

Young. Spotted. Length $5 \frac{1}{4}$ inches.

16. Redstart. Ruticilla phoenicurus (Linnæus). Sylvan. Spring to autumn in Great Britain; Ireland, breeds in co. Wicklow.

Rump and tail chestnut; axillaries chestnut, or rufous.

Male in spring. Black line in front of the white forehead; chin, throat, and sides of neck black; back grey ; centre of belly nearly white.

Female. Above dull brown; underparts paler; breast shaded with chestnut and white.

Male in autumn much as adult female.

Young. Spotted. Length $5 \frac{1}{4}$ inches.

17. Black Redstart. Ruticilla titys (Scopoli). Not uncommon in autumn and winter on rocky coasts of S.W. of England; elsewhere a straggler.

Tail and rump chestnut-red ; two centre tail-featbers dark; axillaries black, or greyish black.

Male. Cheeks, throat, and breast black; primaries and secondaries edged on outer webs with white; centre of belly nearly white.

Female and young male. Above entirely sooty brown; underparts nearly as dark as the upper. Length $5 \frac{3}{4}$ inches.

C. \& S. Europe, $N$. Africa.

S.W. Africa wintering in W. Africa.

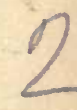


Europe, chiefly

$N$. of the Baltic and N. Asia, wintering in $N$. Africa and India.

\section{5}

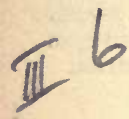

II 3

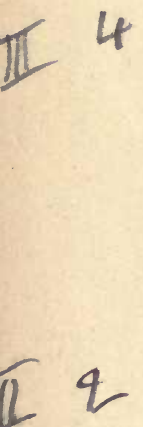

High mountains of Europe and Asia Minor.
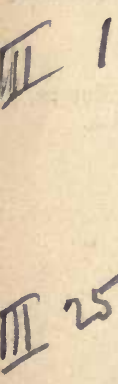

18. Red-spotted Bluethroat. Ruticilla suecica (Linnæus). Irre gular migrant, not yet noticed in Ireland.

Tail brown, with basal two-thirds of all but two centre feathers chestnut.

Male. Chestnut spot in centre of the blue throat.

Female and young male. Below buffish white; a dark band across throat, with occasionally faint marks of blue and chestnut. Length 6 inches.

The more southern White-spotted form, $R$. cyanecula, has been doubtfully recorded as British; the only difference between it and $R$. suecica is that in the former the adult male has a white instead of a chestnut spot. Entirely blue-throated individuals are known as $R$. wolfi.

19. Roвin. Erithacus rubecula (Linnæus). Resident.

Chin, throat, and breast orange-chestnut.

Young in first plumage mottled, each feather orange-buff tipped with black. Length $5 \frac{3}{4}$ inches.

20. Nightingale. Daulias luscinia (Linnæus). Sylvan. Spring to autumn, south and east of an imaginary line drawn through and including East Devon, Glamorganshire, Brecon, Herefordshire, Shropshire, Staffordshire, Derbyshire, and South Yorkshire.

General colour russet-brown above; upper tail-coverts and tail chestnut-brown; underparts buffish white.

First primary longer than primary-coverts.

Young in first plumage spotted like a Robin. Length $6 \frac{3}{8}$ inches.

\section{Subfamily ACCENTORIN无.}

21. Hedge-Sparrow. Accentor modularis (Linnæus). Resident.

Above reddish brown, streaked with blackish brown; chin, throat, and breast bluish grey; belly whitish.

Young. Streaked above and below; no grey or white. Length $5 \frac{1}{2}$ inches.

22. Alpine Accentor. Accentor collaris (Scopoli). Very rare straggler to England.

Chin and throat dull white, with black spot on each feather; wingcoverts tipped with white; tail dark brown, with pale buff tips. Length 7 inches.

\section{Subfamily SYLVIIN A.}

23. Whitethroat. Sylvia cinerea, Bechstein. Sylvan. Spring to autumn.

Back reddish brown; legs pale brown; chin and throat much whiter than the rest of the underparts; quills and wing-coverts edged with pale rufous; iris reddish brown. Length $5 \frac{1}{2}$ inches. 
24. Lesser Whitethroat. Sylvia curruca (Linnæus). Sylvan. 6 Spring to autumn, as far north as the south of Scotland, and has recently occurred in Ireland.

Head and back bluish grey, back suffused with brown; legs lead-colour; iris yellowish white. Length $5 \frac{1}{4}$ inches.

25. Garden-Warbler. Sylvia hortensis, Bechstein. Sylvan. Spring 7 to autumn.

General colour above and tail olive-brown; underparts greyish white. Head same colour as back; axillaries and under wing-coverts buff; chin and throat not whiter than rest of underparts. Length $5 \frac{7}{8}$ inches.

26. Blackcap. Sylvia atricapilla (Linnæus). Sylvan. Spring to autumn.

General colour above ashy brown; chin and throat bluish grey; tail without any white.

Male. Head black. Length $5 \frac{3}{4}$ inches.

Female. Head rufous. Length $6 \frac{1}{4}$ inches.

27. Western Orphear Warbler. Sylvia orphea, Temminck. Sylvan. Two records in England, neither of them satisfactory.

Male. General colour above ashy grey; chin, throat, and underparts white; outer pair of tail-feathers with outer web white, inner web brown; next pair white only at tips; head black.

Female. Like male, but the head only slightly darker than back. Length $6 \frac{3}{4}$ inches.

28. Barred Warbler. Sylvia nisoria (Bechstein). Sylvan. Scarce 0 straggler on migration. Not yet noticed in Ireland.

Male. General colour above brownish grey; underparts whitish, with transverse dark-brown bars; the thighs also barred, as are the upper and under tail-coverts; iris light yellow.

Female. Like male, but less barred. Length $6 \frac{3}{4}$ inches.

29. Dartford or Furze Warbler. Sylvic undata (Boddaert). Resident south of the Thames, rarely north of that river; not in Scotland or Ireland. Local, in gorse-districts only.

Upper parts blackish brown; throat, breast, and sides chestnut-brown; feathers of chin and throat tipped with white; tail long and graduated, half the length of the bird; eyelids and iris red in adults, yellow in young. Length 5 inches.

30. Western Rufous Warbler. Aëdon galactodes (Temminck). s.W. Europe, Three occurrences : Sussex, Sept. 1854 ; Devon, Sept. 1859, Oct. 1879.

Upper parts pale chestnut-brown. Tail long and graduated; the two centre feathers rich reddish buff ; the others reddish buff, except the ends, which are black, tipped with white. Length 7 inches. N. Africa wintering fur-

S. Sweden, C. \& E. Europe wintering in E. Africa.

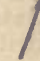
ther south.

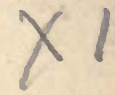


38. Tellow Tree-Warbler. Hypolais icterina (Tieillot). Sylvan. Very rare straggler to England and Ireland, yet common across the Channel (e. g. near Boulogne).

Above olive-green ; below greenish yellow; lores yellow; secondaries broadly margined with buffish white. Legs bluish grey. Length $5 \frac{1}{4}$ inches.

39. Yellow-Browed Warbiler. Phylloscopus superciliosus (J. F. N. Asia, Gmelin). Sylvan. Rare straggler on migration to Englaud and Scotland ; once in Ireland, Oct. 14, 1890.

General colour above olive-green; two greenish-yellow bars across each wing; a pale line on erown of head; white or yellow eye-stripe from base of bill to nape. Length 4 inches.

40. ChifrchafF. Phylloscopus rufus (Bechstein). Sylvan. Spring to autumn.

Smaller than next, and duller in plumage. Legs nearly black. Length $4 \frac{3}{4}$ inches.

Earliest spring migrant. Nest domed and lined with feathers.

41. Willow-Warbler. Phylloscopus trochilus (Linnæus). Sylvan. Spring to autumn.

Much as last, but larger and brighter. Legs light brown. Length 5 inches.

Nest as above.

42. Wood-Warbler. Phylloscopus sibilatrix (Bechstein). Sylvan. Spring to autumn.

Distinct light streak from base of bill over eye to crown; white belly, contrasting with yellow breast and throat. Length $5 \frac{1}{4}$ inches.

Nest domed, but not lined with feathers.

Subfamily REGULIN无. Arboreal. Each nostril covered by a single stiff feather.

43. Gold-Crested Wren. Regulus cristatus, K. L. Koch.

Male. General colour above olive-green, a black streak on each side of the orange-coloured crown.

Female. Less bright than male. Length $3 \frac{1}{2}$ inches.

Smallest of British birds.

44. Fire-Crested Wren. Regulus ignicapillus (C. L. Brehm). Europe. Scarce straggler.

Male. Much as last, but whitish streak over the eye, and a third black streak through eye to the olive-green nape; crown flame-ccloured.

Female. Less bright than male. Length 4 inches.

Europe,

wintering in S. Africa. 


\section{P A R I D \#. Arboreal.}

45. Long-tailed Tit. Acredula caudata (Linnæus). Resident.

Male. Entire head white. In the British race (named $A$. rosea) both sexes have the crown black with white stripe down the centre. Intermediate forms occur.

Female. Crown white with dusky lateral stripe.

Adults. Eyelids orange-red, yellow in young. Length $5 \frac{1}{2}$ inches including tail $3 \frac{1}{2}$.

46. Great Tit. Parus major, Linnæus. Resident.

I 44 Male. Crown bluish black; cheeks white; black stripe along the middle of the greenish-yellow breast and belly.

Female. Similar, but black stripe below not so extended. Length 6 inches.

47. Bude Tiт. Parus coeruleus, Linnæus. Resident.

Crown and wing-coverts azure-blue. Length $4 \frac{1}{2}$ inches.

48. Conl Tit. Pamus ater, Linnæus. Resident.

Head black; nape and cheeks white; wing-coverts tipped with white, forming two bars on the wing; back bluish grey in winter. Length $4 \frac{1}{4}$ inches. The Coal Tit found in British Islands is also separated as $P$. britannicus because the back is brownish in winter, in summer plunnage there is scarcely any distinction ; intermediate forms occur.

49. Marsh-Tiт. Parus palustris, Linnæus. Resident, as far north as the Forth.

Back greyish brown; crown, chin, throat, and nape glossy black. Length $4 \frac{1}{2}$ inches.

Europe. 50. Crested Tit. Parus cristatus, Linnæus. Resident only in the pine-forests of Central Scotland.

General colour greyish brown; throat black; crown dull black, all the feathers tipped and edged with white, and the hinder feathers long and pointed, forming a conspicuous crest. Length $4 \frac{1}{4}$ inches.

\section{PANURID正.}

51. Bearded Reedirga. Panurus biarmicus (Linnæus). Resident, but very local ; only found among reed-beds.

Tail fawn-coloured, about three inches long, graduated, and slightly curving downwards.

Male. Bill yellow; head grey; black moustachial stripe. General colour above tawny buff.

Female. Paler : no moustachial stripe; head fawn-colour.

Young. Like female, but head and back slightly striped with black. Length 6 inches. 


\section{S ITTID无.}

52. Nuthatch. Sitta casia, Wolf. Arboreal. Resident in England; very rare in Scotland; not yet in Ireland.

Bill longer than head. Above slaty grey; throat whitish; rest of underparts cinnamon-buff, lightest next the throat; legs dull brown. Length $5 \frac{1}{2}$ inches.

\section{CERTHIID无.}

53. Tree-creeper. Certhia familiaris, Linnæus. Arboreal. Resident.

Bill slender, curved downwards, and pointed. Above brown, spotted with paler brown; below white. Tail graduated or cuneiform, reddish brown, with stiff points. Length 5 inches.

54. WALI-CREEPER. Tichodroma muraria (Linnæus). Twice: Norfolk, 1792 ; Lancashire, 1872. A rock-haunting bird.

General colour slate-grey; all the primaries, except the first three, crimson on the basal half of the outer web; throat black in summer, white in winter; bill as in last, but longer in proportion. Length 6 inches.

\section{TROGLODYTID无.}

55. Wren. Troglodytes parvulus *, K. L. Koch. Resident.

Above reddish brown; breast whitish brown; tail closely barred with black, and much more rufous 'than back. Hind toe as long or longer than middle toe. Length 4 inches.

\section{N C LID 王.} 0
56. Dipper, or
WATER-OUZEL.
Cinclus aquaticus, Bechstein. Resident.

Head and upper parts dark brown; throat and chest white; flanks grey ; breast chestnut-rufous; belly black. Length 7 inches.

The northern or mountain race (called C. metanogaster), without any chestnut on the breast, occasionally visits the East of Engtand. The two forms completely intergrade.

\section{O R I O L I D E.. Sylvan.}

57. Golden OrIole. Oriolus galbula, Linnæus. Spring to autumn, but rarely allowed to breed.

9. Male. Head and general colour goiden yellow. Black spot between crimson eye and dull red bill; wings black, with yellow tips to secondaries. Tail : outer feathers with more than terminal half yellow.

Female. Greenish yellow above; outer tail-feathers tipped with yellow.

* Unfortunately the Wren found on St. Kilda has been, without sufficient cause, described as a distinct species, T. hirtensis; consequently it has been almost if not quite exterminated by collectors.

Mountains of C. \& S. Europe, c. Asia, and Abyssinia.
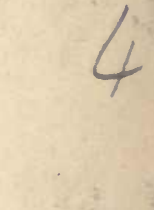
63. Magpie. Pica rustica (Scopoli). Sylvan. Resident.

Long graduated iridescent green tail ; rump greyish white. Length $16-18$ inches, tail 10-11.

64. JACKDAw. Corvus monedula, Linnæus. Resident.

Black ; ear-coverts, nape, and sides of neck grey ; belly leaden black. Young. Little or no grey on nape. Length 14 inches.

65. Raven. Corvus corax, Linnæus. Resident.

Largest of British Passeres.

General colour glossy steel-black; throat-feathers pointed; tail slightly cuneate. Length 24 inches.

66. Carrion-Crow. Corvus corone, Linnæus. Resident.

Black, with metallic gloss; nostrils covered with bristly feathers; base of body-feathers whitish. Length 18-19 inches.

67. Hooded Crow. Corvus comix, Linnæus. Resident in Scotland and Ireland; in England a winter visitor.

Head, throat, wings, thighs, and tail-feathers black; the rest of plumage dull grey. Length 18-19 inches.

68. Rоок. Corvus frugilegus, Linnæus. Sylvan. Resident.

Black, with blue gloss.

Adults. With bare scurfy skin on forehead, lores, and throat.

Young in first plumage have these parts feathered, and resemble young Carrion-Crows, but the bases to the body-feathers are grey and the bill is slender. Length 18-20 inches.

L A N I I D 无. Sylvan. Young barred below.

69. Great Grey Shrike. Lanius excubitor, Linnæus. Autumn to N. Europe. spring.

Forehead white. Above bluish grey, below white. Tail graduated, the four centre feathers black, the next tipped with white, the white gradually increasing in the others until the outside feathers are nearly white. Two white bars on the wing when folded. The race with only one bar on wing (called Lanius major) has a more northern habitat, and visits in England in winter. Length 9 inches.

70. Lesser Grey Shrike. Lanius minor, J. F. Gmelin. Four occurrences : Scilly Is., 1851; Norfolk, 1869, 1875; Devon, 1876.

First primary very short, less than one third of second; tail even.

Male. Above grey; forehead and feathers from bill, round eye to ear-coverts, black; breast and flanks with a roseate blush. Wing-bar
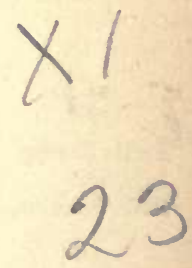
white.

Female. Less black on fore part of head.

Young. Has only black round and behind eye. Length 8-9 inches.

C. \& S. Europe, except Peninsula, Asia Minor, wintering in S. Africa. 
71. Red-baCked SHRIKe, or "BUtChER-BIRd." Lanius collurio, Linnæus. Spring to autumn, rare in Scotland-one occurrence in Ireland.

Male. Scapulars dull brick-red, uniform with the back; crown, hind neck, and rump grey ; chin white; breast with roseate tinge.

Female. Above brownish grey; tail brownish red. Underparts white; sides of neck, breast, and flanks barred with brown.

Young. Above reddish brown; below pale brown; above and below barred with blackish brown. Length $7 \frac{1}{2}-8$ inches.

Asia Minor and Europe from Baltic, wintering in Africa.

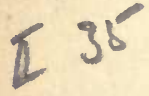

Arctic Europe, Asia, and N.W. America.
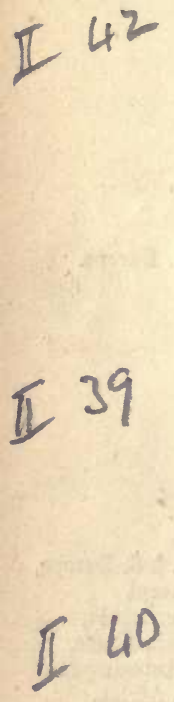

72. Woodchat Shrike. Lanius pomeranus, Sparrman. Rare straggler on migration, but not to Scotland or Ireland.

Male. Forehead black; centre of crown and nape chestnut; scapnlars white, forming a large white patch on each side; rump and underparts white; white alar bar, or speculum, formed by the white outer web of base of primaries.

Female. Like the male, but markings ill-defined and not so bright.

Young. Much like young of last, but lighter. Scapulars and rump paler; plumage vermiculated with dark brown. Length $7 \frac{1}{2}$ inches.

\section{A M P ELID压.}

73. WAxwING. Ampelis garrulus, Linnæus. Irregularly in severe winters; sometimes in great numbers, but not of late years.

Male. General colour brownish grey; long erectile crest; black band from nostrils to nape; chin and throat black. Tail short, tipped with yellow; under tail-coverts deep chestnut. Secondaries tipped with small scarlet wax-like ends; some of the tail-feathers rarely thus tipped.

Female. Like male, but with fewer wax tips on wings, none on tail. Length 8 inches.

\section{U S C I C A P I D AE. Nostrils more or less covered by bristly hairs.}

74. Spotmed Flycatcher. Muscicapa grisola, Linnæus. Spring to autumn.

Ashy brown above; forehead lighter than head, which is mottled with streaks of darker brown; breast white, with brown streaks; axillaries fawn-coloured.

Young. Spotted. Length $5 \frac{1}{2}$ inches.

75. Pied Flycatcher. Muscicapa atricapilla, Linnæus. Sylvan. Spring to autumn; very local breeder; has visited Ireland.

Male in spring. Above black, except white forehead and white wingbar; axillaries and underparts white; quills brownish black. Tail black, three outer feathers on each side having two-thirds of the outer web from the base white.

Female, male in winter, and young. Above brownish grey; underparts dirty white. Tail as in male, but duller. Length 5 inches. 
76. Red-breasted Flycatcher. Muscicapa parva, Bechstein. Rare straggler to England and once to Ireland on migration.

Tail blackish brown; the base of all, except the two centre feathers, more or less white.

Male. General colour above ashy brown. Throat and upper breast orange-red.

Female and male in winter plumage have the throat dull buff. Length 5 inches.

\section{HIR U N DI N I D 屟. Spring to autumn. Wings} with nine visible primaries.

\section{Swatlow. Hirundo rustica, Linnæus.}

Head, back, and rump steel-blue. Throat and forehead chestnut-red, with complete blue-black band across the lower part of the throat; underparts buff to creamy white. Tail strongly forked; two outer feathers greatly prolonged. Length $8 \frac{1}{2}$ inches.

\section{Martis. Chelidon urbica (Linnæus).}

Rump white; under surface pure white; tail much forked; toes feathered. Length $4 \frac{3}{4}$ inches.

\section{Sand-Martix. Cotile riparia (Linnæus).}

Above mouse-coloured; underparts white, except greyish band between chest and throat. Minute tuft of feathers just above hind toe. Young. Feathers above edged with buffish white. Length $4 \frac{3}{4}$ inches.

FRINGILLID E⿸. Wings with nine visible primaries.

30. Greenfirch. Ligurinus chloris (Linnæus). Sylvan. Resident. 24 Adult mule. General colour above olive-yellow, shaded with ashy grey; crown more ashy than back; axillaries bright yellow; primaries edged with bright yellow reaching to the shaft; tail black at ends, yellow at the base; outer tail-feathers yellow at base of both webs.

In winter. Browner.

Female. Browner than male; primaries only margined with yellow; outer tail-feathers edged with yellow on outer web only.

Young male. Like female, but has primaries and tail as in adult male. Length 6 inches.

81. Hawfircir. Cocothraustes vulgaris, Pallas. Sylvan. Resident.

Bill very large. Fifth and next four primaries shaped like a billhook.

Adcult male. General colour above chestnut-brown; crown reddish brown, lightest on forehead; hind neck grey; black patch on chin; larger wing-coverts tipped with white; sides of body and flanks vinaceous brown; bill bluish; iris greyish white.

Female. Head ashy brown; secondaries edged with bluish grey; flanks as in male. 
In winter. Bill fleshy white.

Young. Spotted, no grey at back of neck or black patch on chin; lower breast and flanks spotted and barred with brown; iris brown. Length 7 inches.

82. Goldfinch. Carduelis elegans, Stephens. Resident, but decreasing.

Bill nearly conical, sharp-pointed.

Adult. General colour above ruddy brown. Forehead, upper throat, and cheeks crimson; hinder crown and sides of neck black; outer web of basal half of primaries, except the first, and the larger wing-coverts, brilliant yellow.

Young. Mottled, no red or black on head, that part being greyish brown. Length 5 inches.

83. Siskin. Carduelis spinus (Linnæus). Arboreal. Occasionally breeds in England, regularly in Scotland and Ireland.

Adult male. Above yellowish green; cheeks, throat, and breast bright yellow; flanks streaked with black; crown and small patch on chin black; tail blackish, all but the two centre feathers yellow at the base.

Female. No black on head or chin; throat uniform dull white. Length $4 \frac{1}{2}$ inches.

C. \& S. Europe, Asia Minor, N. Africa.

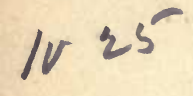

84. Serin Finch. Serinus hortulanus, K. L. Koch. Sylvan. Very rare straggler to England; importation suspected.

Bill conical, short, stout and blunt.

Adult male. General colour above pale brown, each feather edged with yellow, and streaked with black on the centre; crown like the back; forehead, nape, eye-stripe, throat, and breast yellow; flanks streaked with black.

Female. Like male, but duller; throat, breast, and flanks streaked with dark brown. Length $4 \frac{1}{2}$ inches.

85. House-Sparrow. Passer domesticus (Linnæus). Resident.

Aclult male. Crown, nape, and rump ashy grey, with a chestnut streak IV 4 on each side of head; throat black; ear-coverts white; general colour above chestnut, streaked with black on back.

Female. Lacks black throat of male; above dingy brown, streaker with black; pale eye-stripe; rump ashy brown.

Young. Like female, but can always be known by the yellowish skin - at angle of gape. Length 6 inches.

86. Tree-Sparrow. Passer montanus (Linnæus). Resident.

Sexes alike. Smaller than last. Always nests in hotes of trees, thatch, and buildings.

Adult. Crown and nape uniform vinaceous chestnut; throat black; ear-coverts ashy white, with black patch on lower part; rump ashy brown.

Young. Duller, but show indistinctly markings of adults. Length $5 \frac{1}{2}$ inches. 


\section{7. Сhafrinch. Fringilla colebs, Linnæus. Resident.}

Adult male. Forehead black; head slate-grey; back rufous; earcoverts and underparts vinous red; rump olive-green. Two white bars on wing.

Male in winter. Duller, the slate-grey feathers having brown tips, and the white on wings is tinged with yellow.

Female. Head and back ashy brown; below pale brown; rump yellowish green.-In winter is browner, and the white on the wings has yellow tinge. Length 6 inches.

88. Bramblivg. Fringilla montifringilla, Linnæus. Autumn to spring.

Rump white, intermixed with black; axillaries and smaller inner wingcoverts pale yellow.

Male in summer. Head and upper back blue-black; throat and chest orange; flanks spotted with black ; bill bluish.

Male in winter. Black parts edged with buff; throat duller, shaded with sandy buff; bill yellow.

Female. Head and upper back dark brown; rest of plumage much as male in winter, but less bright. Length $6 \frac{1}{5}$ inches.

89. Linver. Acanthis cannabina (Linnæus). Resident.

Adult male. General colour above reddish brown; forehead and breast rich crimson; rump paler than back; wing-coverts uniform chestnutbrown, like the back, without white edging; throat whitish. In winter the red colour is obscured by pale edgings to breast-feathers, which wear off.

Female. Has no red on head or breast; sides of face dark ashy, like the head; bill dusky.

Young. Like female, but spotted. Length $5 \frac{1}{2}-6$ inches.

90. Mealy Redpoll. Acanthis linaria (Linnæus). Autumn to sspring.

Adult male in summer. Above light brown, streaked with blackish brown; fore crown carmine ; chin black ; throat and breast pink ; rump ashy white, tinged with crimson and streaked with brown; wing-coverts tipped with whitish, forming a double wing-bar.

Female. Like male, but only red on the head. In winter the rump is whitish, and the throat and breast are fringed with ashy-white tips. Length 5 inches. The northern race called $A$. holboelli, larger, with a " very much larger bill," is stated to have occurred in England (Sharpe, Cat. Birds British Museum, vol. xii. p. 250).

91. Lesser Redpotl. Acanthis rufescens (Vieillot). Resident.

30 Similar to last, but smaller and more rufous, the rump dusky brown, and the bands on wing reddish buff. Length $4 \frac{1}{4}$ inches.

92. Twite, or Mountain-Linnet. Acanthis flavirostris (Linnæus). Breeds from Derbyshire northwards; a winter visitor to the south.

No red on forehead or breast ; bill yellow in adults; dusky in young.
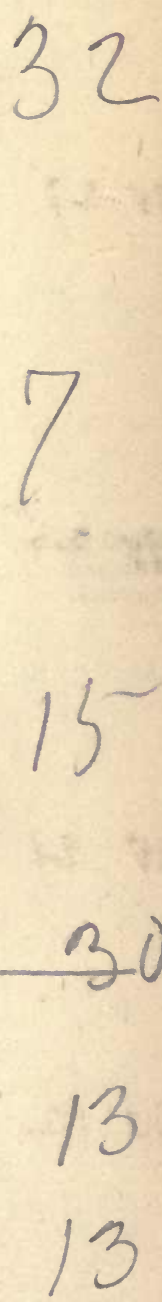
Adult male. Above ruddy brown, feathers streaked with black down the centre, those on the back with pale margins; rump purplish red; throat and fore neck clear reddish brown, the latter streaked with dark brown; axillaries reddish brown, with black centres.

Female. Like male, but lighter and without the rosy rump, which is uniform with the back. Length 5-5 $\frac{1}{4}$ inches.

N.E. Europe, N. Asia, wintering in S. Asia.



IV

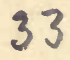

North Europe, Asia, and America.
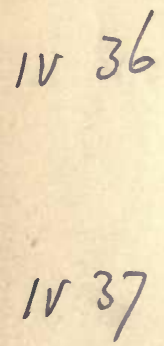

93. Scarlet Grosbeak. Pyrrhula erythrina, Pallas. Two occurrences : Sussex, 1869 ; Middlesex, 1870.

Wings shorter than tail.

Adult male. General colour rosy or crimson; head crimson; rump brighter than back.

Female. General colour above olive-brown; feathers with dusky centres; rump same colour as back; middle and greater wing-coverts tipped with yellowish white, forming a double wing-bar; throat dull white streaked with brown. Length $5 \frac{1}{2}$ inches.

94. Bullfinch. Pyrrhula europaca, Vieillot. Sylvan. Resident.

Wing longer than tail. Nostrils completely hidden by bristly plumelets. Rump white.

Male. Head and chin black; ear-coverts, throat, breast, and belly vermilion; nape and back ash-grey.

Female. Head black; nape and back greyish brown; below pale brown.

Young. Mottled; less bright than female; rump washed with brown. Length 6 inches.

95. Pine-Grosbeak. Pyrrhula enucleator (Linnæus). Arboreal. Only one or two genuine occurrences, and those perhaps introduced.

Adlult male. Head, neck, back, rump, and breast crimson; axillaries ashy grey.

Female. No rosy colour; head olive-yellow; general colour above ashy; feathers of back with dusky streaks; axillaries ashy grey, edged with whitish. Length 8-9 inches.

96. Crossbill. Loxia curvirostra, Linnæus. Local, and breeding very early in season, chiefly where pine-trees occur. Arboreal.

Points of bill crossing each other.

Adult male. General colour red, brightest on rump; but sometimes breeds in yellow plumage of female, very faintly streaked with red in a few places.

Female. Olive-yellow where red in male, brightest on rump.

Young. Like female, but streaked above and below with dark brown. Length 6 inches.

The so-called Parrot Crossbill (L. pityopsittacus) is a Northern form of the Common Crossbill, with the bill very much stouter, and is usually a larger bird. 
97. Two-barred Crossbill. Loxia bifasciata (C. L. Brehm). . Rare straggler in winter. Arboreal.

Aclult male. General colour above pale scarlet, underparts rosy. Middle wing-coverts white, with dusky bases; greater coverts blackish, tipped with white, forming a second wing-bar.

Female. Olive-yellow where red in male. Length 6 inches.

The American race, L. leucoptera, said to have occurred in this country, resembles the European form, except that the scapulars are darker.

98. Black-headed Buntivg. Emberiza melanocephala, Scopoli. Three occurrences (females and young birds): Sussex, 1868; Notts, 1884 ; and Scotland, 1887.

Male. Head and ear-coverts black; back and rump chestnut; chin and underparts bright yellow.

Female and young. Head brown, streaked with black; back and rump pale chestnut, washed with yellow; under tail-coverts yellow. Length $6-7$ inches.

\section{CoRn-Buntivg. Emberiza miliaria, Linnæus. Resident.}

Sexes alike. General colour greyish brown, streaked with dark brown; light eyebrow ; tail brown, with edges and tips of buffy white, no other colours in plumage. Length 7 inches.

\section{Yellow Hammer. Emberiza citrinella, Linnæus. Resident.}

Male in summer. Head lemon-yeliow ; back rufous, streaked with dark brown; rump chestnut; under surface yellow:

In winter. Head marked with brown, and generally less bright.

Female. Head less yellow, crown streaked with black; throat and breast striped with blackish. Length $6 \frac{1}{4}-7$ inches.

101. Cirl Buntiva. Emberiza cirlus, Linnæus. Resident in south of England; has occurred three times in Scotland; not authenticated in Ireland.

Least wing-coverts olive-green; rump olive-brown.

Male. Chin, throat, and line from bill through eye to nape black; eyebrow yellow; yellow crescent under the black throat; upper chest dull olive, bordered below by chestnut; belly dull yellow.

Female. Much like female of Yellow Hanmer, but wanting the yellow colouring.

In winter, colours of male less bright, the black parts obscured by light margins. Length 6 inches.

102. Brandt's Siberian Buntisg. Emberiza cioides, Brandt. Once reported from Yorkshire ('Ibis,' 1889, p. 293).

Adult male. General colour above chestnut, each feather streaked with black ; band of chestnut across breast ; crown and ear-coverts chestnut; lores black. Length 6 inches.

Female. Paler.

E. Europe, Asia Minor, and Persia, wintering in India.
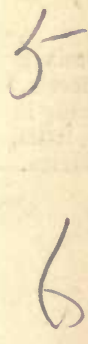

N.E. Europe to

E. Siberia
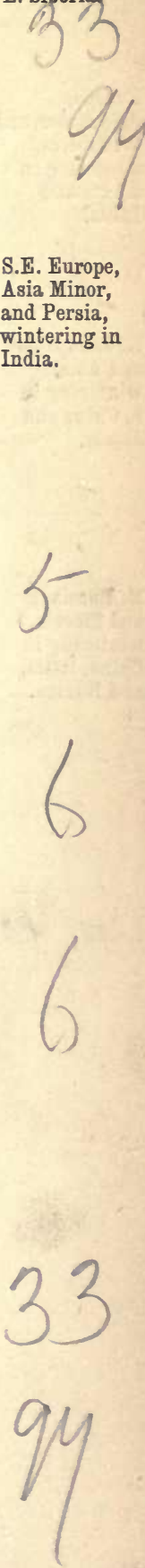
Winter. As in other Buntings, the bright markings are obscured by pale margins to the feathers. Females and young males have the crown streaked with black.

Europe, Asia Minor, and W. Siberia, wintering in Africa and India. iv 16

\section{N. Europe} and Asia, wintering in S. China and Japan.

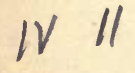

N. Russia and Siberia, wintering in China, India, and Burma.

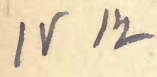
tion.

103. Ortolav. Emberiza hortulana, Linnæus. Straggler on migra-

Male. General colour above pale reddish brown; head greenish olive; cheeks, throat, and axillaries pale yellow ; neck and chest greenish olive; rest below cinnamon; bill reddish brown.

Female. Paler than male; lower throat streaked with brown. Length 6 inches.

104. Rustio Bunting. Emberiza rustica, Pallas. Three occurrences: Sussex, Yorkshire, Middlesex.

Male in spring. Crown and sides of head black; streaks on flanks and breast chestnut; broad white stripe over eye; above chestnut streaked with black; rump and band across chest chestnut; belly white.

Female. Head and upper parts brown, streaked with blackish; rump tinged with rufous. Length $5-5 \frac{1}{2}$ inches.

\section{Litrue Bunting. Emberiza pusilla, Pallas. One record:} Brighton, 1864.

Mate in spring. Centre of crown vinous chestnut, with black band on each side; eye-stripe, lores, sides of face, and throat vinous chestnut.

Female. Like male, but not so richly coloured on throat.

Young. Throat white, no chestnut on breast or flanks. Length $4 \frac{3}{4}$ inches.

106. Reed-Bunting. Emberiza schoeniclus, Linnæus. Resident.

Male in spring. Head and throat black; cheeks white; eye-stripe white; white collar from bill round nape; rump bluish grey; lesser wing-coverts chestnut.

In autumn the black is hidden by rufous edgings, and the white by sandy brown edgings.

Female. Head and ear-coverts reddish brown streaked with black.; breast and flanks white, streaked with blackish. Outside web of second tail-feather white. Length 6 inches.

107. Snow-Bunting. Plectrophenax nivalis (Linnæus). Chiefly autumn to spring, but a few pairs breed on mountains in N. of Scotland.

Tail : six centre feathers black, fringed externally and round tip with white; three outer pairs white, with black at end of outer web; claw of hind toe elongated, but not longer than hind toe.

Male in summer. Head, neck, and under surface white; above black; wing-coverts white; bill black.

Female. Dark brown and white; secondaries white.

Male and female in winter. Crown reddish brown; feathers on upper parts broadly edged with reddish brown; bill yellowish with dark tip. Length $6 \frac{1}{2}-7$ inches. 
108. Lapland Bunting. Calcarius lapponicus (Linnæus). Irregular straggler, autumn to spring.

Hind claw nearly straight, longer than hind toe. Tail brown, outer feathers mostly white.

Adult male in summer. General colour above black; broad white streak from eye to breast; throat black; hind neck and sides of neck bright rufous.

In autumn. The black and rufous parts are concealed by pale edges to feathers.

Female. Crown blackish, with light edgings; buffish eyebrow; nape duller than in male; throat buffy white.

In winter. General colour greyish brown; light eye-stripe; throat and flanks marked with dark brown. Length $6 \frac{1}{4}$ inches.

MOT ACILLID E⿸. Wings with nine (visible) primaries.

109. White Wagtail. Motacilla alba, Linnæus. Spring to autumn ; 3 has bred in England, and doubtless is often overlooked.

Male. Crown, nape, throat, and breast black; back from nape ashgrey ; front and sides of head white.

Female. Like the male.

In winter. Resembles the next (M. lugubris), but has lighter back.

Young. Undistinguishable from the young of the next. Length 7$7 \frac{1}{2}$ inches.

110. Pied Wagtail. Motacilla lugubris, Temminck. Chiefly spring to autumn, but many resident.

Male in spring. Crown, nape, back, chin, and throat black, the latter uniting with the black on the back and nape; forehead and sides of the head white.

Female. Like male, but has the back slaty grey, with blackish feathers here and there.

Both sexes in winter have the back ash-grey; chin and throat white; back of the head and nape black, with a black crescent on front of neck.

Young. In first plumage have entire head ash-grey; face washed with yellow; the black crescent on front neck gradually developing from a small spot to a full crescent. Length $7-7 \frac{1}{2}$ inches.

4 111. Grex Wagtail. Motucilla melanope, Pallas. Resident in hilly and rocky districts ; elsewhere autumn to spring.

Under tail-coverts brighter yellow than belly.

Male in summer. Above bluish grey; white eye-stripe; rump and upper tail-coverts greenish yellow; underparts yellow; throat black.

Female. Resembles the male, but has the throat white, or white with very rarely a few black feathers.

Young. Above tinged with brown; throat and eyebrow buff.

In winter. Both sexes are alike, having a white throat. Length 7-7 $\frac{1}{2}$ inches, tail about $3 \frac{1}{2}$. 
119. WATER-Pipit. Anthus spipoletta (Linnæus). Very rare, on S.\& c. Europe, migration, in S. England.

White eye-stripe; below pale rosy; chest uniform, without streaks. ing in Africa. Light pattern of outer tail-feathers white. Hind claw long and straightened.

Young. Undistinguishable in plumage from those of $A$. obscurus. Length $6 \frac{1}{2}$ inches.

120. Tawny PIPIT. Anthus campestris (Linnæus). Irregular migrant to S. and E. England.

General colour of upper surface dull greyish brown, darker on centre of feathers; broad buffy-white eyebrow ; throat whitish; underparts uniform pale buff; wing-coverts edged with pale buff, varying much in depth of colour; light partern of outer tail-feathers white. Hind claw stout and slightly curved, about equal in length to hind toe. Length $6 \frac{1}{2}-7$ inches.

121. Richard's Pipit. Anthus richardi, Vieillot. Straggler to England; once in Scotland; not yet recorded from Ireland.

Largest of British Pipits. A bove dark brown, with sandy-buff edges to feathers; throat and breast streaked; axillaries sandy rufous; light pattern of outer tail-feathers white. Hind claw long and nearly straight. Leg about $1 \frac{1}{6}$ inches long. Length $7 \frac{3}{4}$ inches.

A L A U D I D E. Wings with nine or more visible primaries.

122. Skт-Lark. Alauda arvensis, Linnæus. Resident.

Breast spotted. Outer tail-feathers white, except inner edge of inner web ; next pair white only on outer web. Hind claw long and straight. Bastard primary very small. Length $7 \frac{1}{4}$ inches.

123. Crested Lark. Alauda cristata, Linnæus. A very rare straggler, even to the South of England, although so common on the Continent only twenty-two miles off.

General ground-colour varies much from greyish brown to buffish brown. Conspicuous occipital crest; axillaries buff; outer web of outer tail-feathers buff. Length $6 \frac{3}{4}$ inches.

124. Wood-Lark. Alauda arborea, Linnæus. Resident in Great Britain up to Stirlingshire, but very local; also in Ireland.

Light streak over eye; primary-coverts tipped with white, showing small white spot on closed wing. First primary long, third primary longest. Tail short; outer feather greyish white at end, and outer web bordered with white, next three tipped with triangular white spots; hind claw curved. Length 6 inches.

S. \& C. Europe, Asia Minor, E. Siberia, wintering in Africa and India.

C. \& E. Asia, wintering in S. China, Burma, Ceylon Europe, and $N$. Africa.

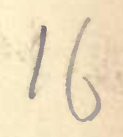

Europe to N. China, N. Africa.

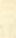

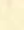

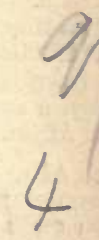


S. Europe and Asia Minor, wintering in Africa and India.

\section{IV}

Asiatic Russia, wintering in S.E. Russia, Turkey, and Asia Minor

IV.

Arctic and subArctic regions, wintering south.

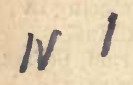

125. Short-TOED LaRK. Alauda brachydactyla, Leisler. Rare straggler on migration : as yet only to England.

Below buffish white; no spots on underparts; but sometimes a streak or two and brownish patch on each side of upper breast. Outer tailfeathers buffish white, except the brown basal half of inner web; the next feather has outer web with buffish white edging. Front claws very short and curved; hind claw straight and rather elongated. Length $5 \frac{1}{2}$ inches.

126. White-winged Lark. Alauda sibirica, J. F. Gmelin. One record: Sussex, 1869.

Bill short and stout, arched above. Head rufous; secondaries white, brown at the base; outer tail-feathers white. Length 7 inches.

127. SHone-LaRK. Otocorys alpestris (Linnæus). Of irregular appearance in autumn and winter on sea-coast. Sometimes in large numbers on the E. coast of Great Britain ; not yet recorded from Ireland.

Hind claw long and nearly straight.

Adult male. T'uft of long erectile black feathers on each side of head above eye; front of crown, patch from bill to below eye, and lower throat black; forehead, eye-stripe, chin, and throat yellowish white; tail black, except two centre feathers, which are brown, and the two outer feathers margined on outer web with white. Length 7 inches.

Female. Less black on crown.

Female and young male have no black ear-tuft, and young females no yellow on forehead.

In winter. Black parts are not so distinct, and there is more yellow on light parts of head and neck.

\section{Order PICARI 低. Family CYPSELID AE.}

Tail of ten feathers.

\section{Swifr. Cypselus apus (Linnæus). Spring to autumn.}

General colour blackish brown, except small whitish chin-patch; four toes all directed forwards. Length $7 \frac{1}{2}$ inches.

C. \& S. Europe, Asia Minor, and India, wintering in Ceylon and S. Africa.

E. Asia, wintering as far south as Australian region.

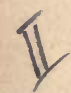

129. Alprine Swift. Cypselus melba (Linnæus). Migratory visitor.

Above greyish brown; chin and belly white, with band of greyish brown across upper breast; toes as in last. Length $8 \frac{3}{8}$ inches.

130. Spine-tailed Swift. Acanthyllis caudacuta (Latham). Two records, both in July: Essex, 1846 ; Hants, 1879.

Head glossy green ; forehead and throat white; spiny shaft on each tail-feather protruding beyond the web; rump and back brown; centre of back dirty white. Three toes in front and one behind. Length $8 \frac{1}{2}$ inches. 


\section{CAPRIMULGID正.}

Mouth very wide, extending behind the eyes : tail of ten feathers; claw of middle toe serrated on the inner edge.

131. Nightjar, or "GoatsdCker." Caprimulgus europaus, Linnæus. Spring to autumn.

Male. White spot near end of inner web of three first primaries of each wing, and the two outer tail-feathers on each side tipped with white.

Female. Like male, but without the white marks on wings and tail. Length $10 \frac{1}{2}$ inches.

132. Rufous-Naped NightJar. Caprimulgus ruficoilis, Temminck. S. Spain and One record: Northumberland, 1856.

Much resembles the last, but larger, with mufous nape and more ruddy chin.

Sexes alike, both male and female having white spots on wings and tail. Length nearly 12 inches.

N.W. Africa, wintering

further south:

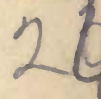

133. Isabelinne Nightjar. Caprimulgus agyptius, Lichtenstein. One record : Notts, 1883.

Sexes alike. General colour mottled sandy grey; basal and outer part of inner webs of primaries white; no white spots on wings or tail. Length $10 \frac{1}{2}$ inches.

PICID E. Two toes in front, two behind.

Subfamily PICIN E. Tail-feathers stiff and pointed : nostrils covered with bristles.

134. Great Spotted Woodpecker. Dendrocopus major (Linnæus). Resident in England; now only a visitor in Scotland; rare in Ireland.

Black and white; scapulars white; back and rump black; under tailcoverts scarlet; iris red.

Male. Nape scarlet.

Female. No red on head or nape.

Young. Crown of head red. Length $9 \frac{1}{2}$ inches.

135. BarRed or Lesser StotTted WoodPecker. Dendrocopus minor (Linnæus). Resident in England; very rare in Scotland and Ireland.

Black and white; middle of back white, barred with black.

Male. Crown of head scarlet. Female. No red on head.

S.W. Asia,
N.E. Africa.

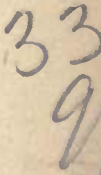

Young. Like adults, but markings less defined. Length $5 \frac{3}{4}$ inches.
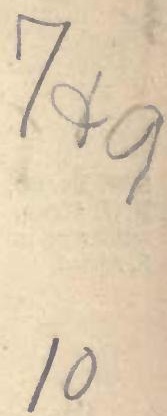
136́. Green WoodPECKer. Gecinus viridis (Linnæus). Resident in England; seldom, if ever, in Scotland; very rarely in Ireland.

General colour greenish. Iris white.

Male. Crown scarlet; moustachial stripe red.

Female. Less red on crown; moustachial stripe black.

Young. Head grey, tipped with scarlet; breast barred with greyish black. Length 13-14 inches.

Subfamily IŸNGINÆE. Nostrils partly covered by a membrane.

137. WRYNeCK. Iÿn torquilla, Linnæus. Spring to autumn.

General colour greyish brown, vermiculated with blackish; below dull white ; throat and breast tinged with buff and crossed with blackish bars. Tail soft and rounded; with six blackish bars; the outer feather on each side so extremely short as to give the appearance of only ten feathers. Length 7 inches.

\section{A L CEDINID 正.}

138. KINGFISHer. Alcedo ispida, Linnæus. Resident, or partially migratory.

Male. Above greenish blue; middle of back, rump, and upper tailcoverts cobalt-blue; throat and patch on each side of neck white; lores black; rest below rich chestnut; bill black. Length $7 \frac{1}{2}$ inches.

Female. Lower mandible reddish at base.

\section{ORACIID AT.}

S. Europe, Asia Minor, N. Africa, wintering in S. Africa.

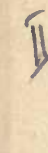

S.W. Europe, N.W. Africa, wintering in S. Africa.

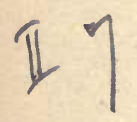

\section{ME R O P I D EA.}

139. Roller. Coracias garrula, Linnæus. Irregular visitor on migration.

Back, scapulars, and tertials cinnamon-brown; inner web of end of primaries blackish brown. Neck, throat, breast, and underparts bluish; rest green or purplish green. Length 13 inches.

140. BeE-Eater. Merops apiaster, Linnæus. Rare straggler on migration.

Bill long, pointed, slightly curved downwards; iris red. Forehead white next bill, then a bluish tinge; crown rich chestnut; chin and throat rich yellow, bordered below by a black line. Tail green, long; two centre feathers an inch longer than others. Length 10-11 inches.

Nотв.-The Blue-tailed Bee-eater, Merops philippinus, has been once recorded, but importation may be suspected. Tail blue. Rather larger than last. 


\section{U P U P I D \&.. Sylvan.}

141. Hoopos. Upupa epops, Linnæus. Spring to autumn; occasionally breeds in England, and would do so annually if not shot on its arrival in spring.

Bill long, thin, slightly arched and pointed. Erectile rich buff crest, tipped with black; the hind feathers of the crest with white before the black tips. Tail black, of ten feathers, with broad white bar across the lower part. Length 10-12 inches.

\section{CUCUIID正. Tail of ten feathers; two toes in front, two behind.}

\section{Cuскоо. Cuculus canorus, Linnæus. Spring to autumn.}

Male. Above bluish grey; chin and neck ash-grey; below white, barred with black. Tail greyish black, graduated, slightly spotted and tipped with white; iris, eyelids, legs, and feet yellow.

Female. Like male, but usually with slight rufous tinge on breast. Females much less numerous than males.

Young. Upper surface and tail clove-brown, barred with pale brown, feathers tipped with white; white spot on nape; iris brown. Length 14 inches.

143. Great Spotted Cuckoo. Coccystes glandarius(Tinnæus). Two occurrences: Galway, 1842, and Northumberland, 1870.

Adults. Crested. Head and nape bluish grey; rest of upper parts greyish brown; wings, scapulars, and tail, except two centre feathers, tipped with white; underparts white. Sexes alike.

Young. Basal two-thirds of primaries chestnut; head blackish brown, without any crest. Length 15-16 inches.

\section{Order STRIGES.}

Family STRIGID无.

144. WhIte or BARN-OwL*. Strix flammea, Linnæus. Resident.

Facial disk complete and large ; tuftless; skin covering orifice of ear (operculum) large.

Above pale orange-buff, speckled with grey and spotted with black and white; underparts and facial disk white, but these parts vary, the former being sometimes marked with black specks, and both are occasionally of a complete buff colour. Iris black. Toes without feathers, covered with a few bristles; middle claw serrated. Length 14 inches.

* This Owl, most useful to man, can be preserved and increased by fixing an old cask (about 18-gallon size) in a tree. The barrel should be placed on its side and have a hole cut in the upper part of the head for the Owls to enter; care must be taken that Jackdaws do not take possession. 
145. Long-eared Owl. Asio otus (Linnæus). Sylvan. Resident.

Eacial disk complete; ear-tufts very long, equal to hind toe and claw; operculum semicircular; iris orange. General colour orange-c buff; above mottled with blackish brown, below streaked and faintly barred with brown. Length 14 inches.

146. Short-eared Owl. Asio accipitrinus (Pallas). Not sylvan. Autumn to spring; but breeds in a few marshy or moorland localities.

Disk and operculum like last; ear-tufts very short.

Above tawny, each feather with dark brown down the centre; below buff, streaked with blackish brown; iris yellow. Length 14-16 $\frac{1}{2}$ inches.

147. Tawny or Brown OwL. Syrnium aluco (Linnæus). Sylvan. Resident in Great Britain; not yet observed in Ireland.

Facial disk complete; no tufts; operculum large; toes feathered; iris blackish.

Two phases of the plumage occur: the grey and rufous. Length 18-19 inches.

N. \& C. Europe and Siberia.

Arctic.

N. Europe and Asia.

C. \& S. Europe, Asia Minor, wintering in Africa.
148. Tengmalm's OwL. Nyctala tengmalmi (J. F. Gmelin). Rare wanderer to England; twice in Scotland: not yet in Ireland.

Disk nearly complete; tuftless; ears with operculum, of unequal size on either side, $i$.e. not symmetrical; toes feathered to the claws.

Above brown, spotted on the head and blotched on the back with white; below greyish white, spotted and barred with rufous brown; tail brown, crossed with five white bars. Length 9-10 inches.

149. SNowr OwL. Nyctea scandiaca (Linnæus). Winter straggler to Great Britain and Ireland, chiefly to the northern districts.

Facial disk incomplete; no operculum; tufts above eyes rarely visible; feet covered to the claws with long feathers.

White, or white with blackish-brown spots or bars, varying much in number of these markings; younger birds most marked; iris yellow. Length 21-26 inches.

150. HAwk-OwL. Surnia ulula (Linnæus). Very rare straggler.

Facial disk nearly obsolete; tuftless; no operculum.

Above dark brown, spotted with white; underparts with numerous small narrow dark-brown bars. Tail long and graduated, narrowly barred and tipped with white. Feet feathered to the claws; iris light yellow. Length 14 inches.

The American form, S. funerea, which has chiefly occurred, has broad chestnut bars on the breast and belly.

151. Scops OwL. Scops giu (Scopoli). Sylvan. Rare straggler on migration to England and Ireland; doubtfully in Scotland.

Facial disk incomplete above eyes; tufted; no operculum. General colour grey, with minute marks of brown and spots of dark brown. Legs feathered; toes bare. Iris yellow. Length $8 \frac{1}{2}-10$ inches. 
152. EagLe-OWL. Bubo ignavus, T. Forster. Very rare wanderer; not yet noticed in Ireland.

Facial disk incomplete above eyes; tufts very large ; no operculum.

General colour above blackish, mottled with tawny yellow. Toes so thickly feathered that the last joint is hidden. Iris orange-yellow. Length 26-27 inches.

153. Litrue Owl. Carine noctua (Scopoli). Rare straggler; not recorded from Scotland or Ireland. Probably many of the records are those of escaped or turned-out specimens.

Facial disk ill-defined; tuftless; no operculum.

Above greyish brown, spotted with white; below white, much streaked with brown; iris yellow; toes without feathers, but covered with bristles. Length $7 \frac{1}{2}-8$ inches.

\section{Order ACCIPITRES. Family VULTURID正.}

\section{Griffor Vulture. Gyps fulvus (J. F. Gmelin). A young} bird obtained near Cork in 1843.

General colour ashy fulvous; head and neck covered with whitish down; ruff of white down. Primaries and tail blackish.

Young. Ruff of tawny lanceolate feathers. Length 40 inches.

155. Egrptian Vulture. Neophron percnopterus (Linnæus). Twice obtained in England.

Adults. Whitish, primaries black ; fore part of head and neck bare of feathers and yellow.

Young. Dark brown; front of head and neck dirty grey. Length 25 inches.

\section{FALCONID无.}

156. Marsh-Harrier. Circus aruginosus (Linnæus). At one time resident in England and Ireland, but now almost exterminated; very rare in Scotland.

Outer web of fifth primary notched ; tail uniform above.

Adult male. Head creamy white, streaked with blackish brown; wingcoverts, secondaries, tertials, and tail ash-grey. (This plumage rarely occurs in this country.)

Female. Head buffish or creamy white, streaked with blackish brown; creamy white margin on shoulders of wings. General colour dark brown; below chocolate-brown; tail brown.

Young of the year. Dark brown; head chocolate-brown. In the next plumage the head, chin, and throat vary from rufous to creamy white, more or less streaked with blackish brown; but in first plumage some are said occasionally to have the head creamy white. Length $21-23$ inches.

Europe, Asia Minor, N. Africa.

S. Europe, N. Africa.

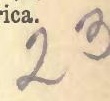

S. Europe, N. Africa, wintering in S. Africa.

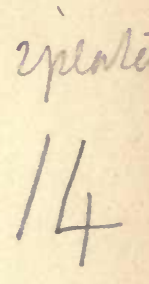


157. Hen-Harrier. Circus cyaneus (Linnæus). Resident, but fast decreasing.

Outer web of fifth primary notched.

Adult male. Pale slate-grey above; throat and chest bluish ash; upper tail-coverts and underparts below centre of breast white.

Female. Above brown; hind neck streaked with whitish; below whitish brown; breast streaked with dark brown; tail brown, with five bands of darker brown.

Young. Like female, but marked with rufous on back; and the bars on the tail are rufous. Length $21 \frac{1}{2}$ inches.

158. Montagu's Harrier. Circus cineraceus (Montagu). Spring to autumn ; occasionally allowed to nest.

Outer web of fifth primary entire. Notch on inner web of the first and outer web of the second primary an inch beyond the tip of the primary-coverts.

Aduit male. Above bluish grey; throat and chest ashy grey. Axillaries, flanks, belly, and thighs wlite, with rufous streaks. One black band across secondaries visible when wings are closed.

Female. Above brown; below buffy white, striped with russet.

Young. General colour dark chocolate-brown, lightest below. Length 18-19 inches.

159. Common Buzzard. Buteo vulgaris, Leach. Resident, but fast decreasing.

Varies so much in plumage as to defy description. Legs and toes short, and bare of feathers; legs about 3 inches long.

Very old birds are sometimes very dark bluish black above, and only slightly marked with light markings on breast.

Adults. Tail brown, barred with twelve or thirteen bands of darker brown.

Young. Upper breast white, with only a few spots; throat brown, with narrow white streaks; tail ashy brown, crossed with ten bars of darker brown. Length 20-23 inches.

160. Rough-Legged Buzzard. Buteo lagopus* (J. F. Gmelin). Winter visitor,

Varies in plumage nearly as much as Common Buzzard.

Legs covered with feathers in front to the toes, as in true Eagles.

Adults. Crown whitish or buffy white, with brown patches on each feather; above deep brown, marked with white and rufous; basal twothirds of tail white, remainder brown, and a broad black band tipped with white.

Young. Less white in plumage; the underparts striped, and the tail has more brown on it. When flying overhead the wings appear lightcoloured, with one dark patch on each wing. Length 23-26 inches.

* Records of this bird having bred in England are utterly untrustworthy 
161. Spotted Eagle. Aquila novia (J.F. Gmelin). Rare straggler

General colour dark reddish brown. Tail nearly uniform brown Asia, above; legs feathered in front to the toes.

Young. Wing-coverts and scapulars with large oval tips of white or brownish white. Length 26 inches.

162. Golden Eagle. Aquila chrysaëtus (Linnæus). Resident in the Highlands and in Ireland, but nearly destroyed in the latter country by poison; seldom visits England.

Legs fecthered in front to the toes, the last joints of which only are covered by three large scales (Aquila). General colour dark brown; nape aud hind neck light brown; thighs uniform dark brown; tail with one greyish bar on under surface.

Young. Basal half of tail white; base of body-feathers white.

Length 32-36 inches.

7 163. White-tailed or Sea-Eagle. Haliaëtus albicilla (Linnæus). Still resident in $\mathbf{N}$. of Scotland and Ireland, on rocky sea-coasts, but nearly exterminated. Immature migrants from the Continent are not infrequent in England, and are often recorded as 'Golden' Eagles.

Lower half of leg bare of feathers; that and the toes covered in front with large scales.

Adult. Bill and iris light yellow; head and neck much lighter than back; tail white.

Young. Bill blackish; iris brown; tail whitish, much mottled with greyish brown.

Length 28-34 inches.

164. Goshawk. Astur palumbarius (Linnæus). Sylvan. Casual visitor.

Above ashy brown; thin white line above ear-coverts; below white, thickly barred with ashy brown; tail ashy brown, with four broad bars of darker brown; iris vellow.

Young. Above brown; below and under wing-coverts light buff, streaked with blackish brown; tail brown, with five bands of darker brown; iris pearly white.

Length : male 19, female 23-24 inches.

(The American Goshawk, Astur atricapillus, has occurred twice, but was probably imported; it resembles the above, but has the underparts closely and irregularly freckled or marbled with ashy brown, not barred.)

165. Sparrow-Hawk. Accipiter nisus (Linnæus). Sylvan. Resident.

I/ Toes rather slender; the middle toe very much longer than the others.

3 Adult male. Above slate-blue; nape mottled with white; cheeks and ear-coverts bright rufous; below white, barred with bright rufous ; iris orange. Length 12 inches.

Female. Wheu very old rarely assumes the same plumage, but very few survive in this country to attain it; the adult females usually have the breast barred with greyish brown, with a redclish patch of downy feathers on the flanks. Much larger than males. Length 15 inches.

Europe, N. Africa, Asia.

, 1.
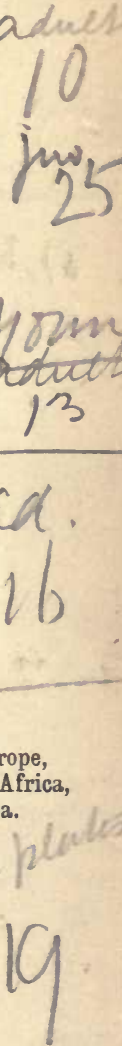
Young. Above brown; nape mottled with white; feathers of back edged with rufous brown; below white, barred with rufous brown; iris pale yellow.

166. Red Krte. Milvus ictinus, Savigny. Sylvan. Resident, but now nearly extinct, and very local.

General colour rufous. Tail rufous and much forked; legs short; iris yellow. Length 24 inches.

Europe, wintering in S. Africa and Madagascar. I.

167. Black Krte. Milvus migrans (Boddaert). One occurrence: Northumberland, May 1866.

Above dark brown, below rufous brown; bill black. Head and throat whitish, with black stripes. Tail brown, not much forked. Length 22 inches.

168. Honey-Buzzard. Pernis apivorus (Linnæus). Sylvan. Spring to autumn. Has bred from New Forest to as far north as Aberdeenshire.

Lores or spaces between eyes and bill covered with feathers; legs finely reticulated all round. (Pernis.)

Adult male. Head ash-grey; above brown; below white, the chest barred and spotted with brown.

Adult female. Like male, but has not the grey head.

Young. Head whitish; upper parts brown, marked with white; below white, streaked with brown.

A dark or melanistic form also occurs, in which the underparts are uniform brown, the young birds being striated with blackish brown.

Length 22-25 inches.

Greenland to

Alaska.

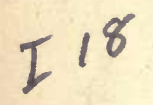

169. Greendand Falcon. Falco candicans, J.F. Gmelin. Irregular winter visitor.

General colour white, more or less marked with blackish brown or brown; no bars on the flanks; bill yellowish white at all ages; cere, legs, and feet yellow in adults, bluish in the young, as also in the Iceland and Gyr Falcons. Length 20-23 inches.

Iceland,

S. Greenland.

170. Iceland Falcon. Falco islandus, J. F. Gmelin. Irregular winter visitor: rarer than the preceding.

1. 16,17 Adult. General colour above brownish grey, each feather barred and 等 rather broad shaft-marks. The light bars across the wing-coverts become white in very old examples, but in $F$. gyrfalco are pale grey. Length $22-24$ inches.

Norway,

Sweden.

171. Gyr-Falcon. Falco gyrfalco, Linnæus. Recorded once or twice in England, and has doubtless been often mistaken for the preceding.

Adult. Feathers on crown of head entirely clark lead-colour, with no white edgings except on the feathers just above the eye and ear-coverts. 
The ear-coverts and feathers on the nape have less white about them than in $F$. islandus. This is especially true of the upper portion of the ear-coverts and the central part of the nape. A dark lead-coloured moustache present in most, but not quite in all; this is absent in $F$. islandus. These differences are partially developed in birds of the second year, but in the first year the two races are not distinguishable by plumage. Length $20-21$ inches.

\section{Peregrine Falcon. Falco peregrinus, Tunstall. Resident.}

Adult. Above bluish grey, paler on rump, barred with a darker tint. Crown, cheeks, ear-coverts, and short moustachial band blackish ; below white, with a buffy tinge on the breast, spotted on the throat and upper breast, and barred on the lower breast with blackish ; cere, eyelids, and legs yellow.

Young. Above brown, with buff margins to feathers; below whitish, with dark brown streaks; tail irregularly barred, tipped with whitish buff; cere, eyelids, and legs blue.

Length 15-20 inches.

173. Новву. Falco subbuteo, Linnæus. May to September, in frooded districts only : rare in Scotland and Ireland.

Adult. Above bluish black, with black moustachial stripe; throat and breast white, occasionally tinged with buff, the breast striped with black; thighs and vent rusty red.

Young. Buff edgings to feathers of back; thighs and vent only very slightly rufous. Very long wings. Length 12-14 inches.

174. Meruiv. Falco aesalon, Tunstall. Resident. Breeding on moorlands, chiefly from Derbyshire northwards.

5 Adult male. Abore slaty blue, with black shaft to each feather; nape rufous ; throat white; underparts rufous, streaked with blackish brown; tail blue-grey, the end broadly banded with black and tipped with white. Length 10 inches.

Female. Very rarely lives to acquire the same plumage as the adult male :-in this country usually resembles young male, being above dark reddish brown, margined with light brown; nape whitish, spotted with buff; underparts white, broadly streaked with brown; tail brown, crossed with narrow bands of lighter brown and tipped with white. Length 12 inches.

175. Red-Footed, Falcon. Falco vespertinus, Linnæus. Rare wanderer on migration; chiefly to England.

Claw's yellowish white.

Adult male. Uniform lead-grey, except reddish-chestnut thighs, vent, and under tail-coverts; legs and feet red.

Female. Above ash-grey, barred with bluish black; head and nape rufous; below uniform dull chestnut.

Young. Like female, but head, nape, and underparts streaked with brown; outside tail-feather with both webs barred. Length 11-12 inches.

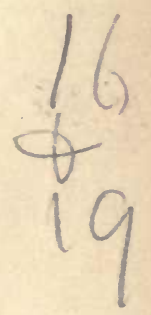

E. Europe, wintering in S. Africa.

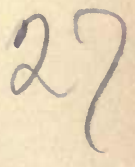


176. Kestree. Falco tinnunculus, Linnæus. Resident or partially migratory.

Adult male. Head, neck, lower back, rump, and tail blue-grey, the latter tipped with white on a broad black band; back pale chestnut, with small black spots.

Female and young. Above entirely rufous, banded with black; tail rufous, with black bands and tipped with a broad black band. Old females occasionally partially assume male plumage, being marked with blue on rump and tail. Length 13-15 inches.

S. Europe, wintering in S. Africa.

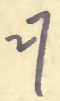

177. Lesser Kestrel. Falco cenchris, Naumann. Four occurrences : Yorkshire, 1867 ; Kent, 1877 ; co. Dublin and Scilly Is., 1891.

Adult male. Much resembles Common Kestrel, but is smaller, and has the back uniform pale chestnut without any spots.

Female. Much as female of last.

Length $12 \frac{1}{2}$ inches. Claws white.

178. Osprey. Pandion haliaëtus (Linnæus). Spring to autumn. Owing to preservation, a pair or two still breed in the Highlands, arriving about 3rd of April. Never known to nest in Ireland.

Adult. Above brown : below white, except brown on breast.

Young. Pale margins to feathers above : tail distinctly barred.

Cere blue. Legs and feet blue, very finely reticulated (or covered with minute scales) and prickly underneath: legs very short, about $2 \frac{1}{3}$ inches long; outer toe reversible ; claws long, much curved, and very sharp. Length 23 inches.

\section{Order STEGA N O PODES.}

Family PELECA N I D 无. Feet entirely webbed or all four toes connected by webs.

179. Conmonant. Phalacrocorax carbo (Linnæus). Resident.

Tail of fourteen feathers.

Adult. General colour above purplish black. In spring slender white plumes on head and neck and white patch on thighs. These white marks are lost after breeding-season is over. Length 36 inches.

Young. Brown above, whitish below.

180. ShaG, or Green Cormorant. Phalacrocorax graculus (Linnæus). Resident on rocky, caverned coasts.

Tail of twelve feathers.

Adult. General colour shiny blackish green without any white. In early spring a crest curled forwards on front of head. Length 27 inches.

Young. Brown above, whitish below.

181. Gannet. Sula bassana (Linnæus). Resident.

Adult. Head and neck buffish white; the rest white, except the black primaries and primary-coverts; tail long and wedge-shaped. 
Young. Head, neck, and upper plumage blackish brown, spotted with white; below white, very thickly covered with blackish-brown spots, but vary much. Length 30 inches.

\section{Order HERODIONES. Family ARDEIDE.}

\section{Common Heron. Ardea cinerea, Linnæus. Resident.}

Male. General colour ashy grey; crown white; crest and nape black; hind neck pale grey ; sides of breast black.

Female. Crest less developed and plumage duller.

Young. Crown ashy; sides of breast striped with black; no plumes on back. Length 36 inches.

183. Purple Heron. Ardea purpurea, Linnæus. Straggler to England on migration; once in Scotland; once in Ireland.

Adult. Crown and crest black, with purple sheen; back, wings, and tail dark slate-grey; plumes on back pale chestnut; under wing-coverts chestnut; thighs rufous buff; breast rich maroon-red.

Young. General colour above rusty red; below brownish white. Length 30-32 inches.

184. Great White Heron. Ardea alba, Linnæus. Very rare c. \& S.E. straggler to Great Britain; not observed in Ireland.

Entirely white; bill and iris yellow; legs and feet black.

In summer. Has bill black and many very long filamented plumes on back. Length 36-42 inches.

185. Litrte Egret. Ardea garzetta, Linnæus. One authentic record : S. Furope, Devon, 1870.

Entirely white; bill and legs black; iris yellow.

In summer. Has long filamentous plumes on back, and two or three Asia, Japan and Ceylon, to N. Australia, long feathers pendent from crown. Length 20 inches.

186. Buff-backed or Cattle Heron. Ardea bubulcus, Audouin. One occurrence: Devon, 1805.

In summer. Crown, nape, feathers hanging from lower neck, and plumes on back reddish buff; these feathers are elongated and bair-like, especially on the back; rest of plumage white; bill reddish at base, yellow at tip ; iris rich pink, with golden ring round pupil.

In winter. Entirely white, except a patch of reddish buff on head; bill and iris yellow. Length 18 inches.

187. Squacco Heron. Ardea ralloides, Scopoli. Straggler to England on migration; rarely to Scotland or Ireland.

Head light buff, with crest of from eight to ten elongated, narrow, pointed white feathers, bordered at the sides with black; plumes on back dark reddish brown to light buff, long and hair-like; wings, rump, tail, and lower parts, except the buff feathers pendent from neck, white; bill leaden blue at base, black at tip. Length 18 inches.

Europe, Asia Minor N. Africa, wintering in S. Africa. 
N. America and Antilles.

men

Europe in summer. Asia, Africa, N.\& S. America.

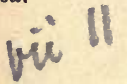

Europe, W. Asia, wintering in Africa.
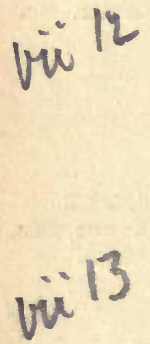

N. America to as far $\mathrm{S}$. in winter as Guatemala. in

[188. Green Heron. Butoridles virescens (Linnæus). One occurrence in Cornwall, possibly an escaped bird. (Ibis, 1890, p. 386.)

Crown, scapulars, wing-coverts, and inner secondaries glossy dark green; neck purplish chestnut ; axillaries purplish grey. Length 16 inches.]

189. Night-Heron. Nycticorax griseus (Linnæus). Not uncommon on migration.

Crown, nape, and back brownish black, with green gloss; wings and tail ash-grey. Crest usually of three, but rarely of as many as six long, narrow, white feathers pendent from nape; legs yellow; bill black; iris red. Females less brightly coloured.

Young. Without crest; above dark brown, spotted with white; below dull white, striped with dark brown. Length 21-24 inches.

\section{Little Bittern. Ardetta minuta (Linnæus). Spring to} autumn. Recorded as having bred in Norfolk.

Male. Crown, nape, back, tail, wing-quills, and upper surface of bill black, with greenish gloss; underparts buff; lower neck-feathers elongated; feathers of upper breast blackish brown, margined with buff; iris yellow.

Female. Crown blackish; above chestnut-brown, margined with buff; primaries dark brown.

Legs greenish yellow; tail of ten feathers. Length 12 inches.

191. Bittern. Botaurus stellaris (Linnæus). Formerly resident, but now chiefly a winter visitor.

Crown and nape black; general colour buff; a large ruff on front of neck; the back irregularly marked with black; primaries chestnut, barred with blackish; tail of ten feathers. Length 28-29 inches.

192. American Bittern. Botaurus lentiginoeus (Montagu). More than twenty occurrences in Great Britain and Ireland.

Much resembles last, but smaller; bill more slender; plumage above finely vermiculated; primaries uniform blackish brown, not barred. Length 27 inches.

\section{CICONIID无.}

Europe, Africa, W. \& C. Asia, passing $\mathrm{S}$. in winter.

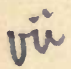

Europe, Asia, Africa.

193. White Sronk. Ciconia alba, Bechstein. Irregular visitor on migration, and was so, according to record, even 350 years ago.

White, except primaries, secondaries, scapulars, large wing-coverts, and bare space round eye, which are black. Bill and legs red. Length 42 inches.

194. BцАск Stork. Ciconia nigra (Linnæus). Scarce wanderer on migration, not observed in Scotland or Ireland.

'Head, neck, and upper parts blackish with metallic gloss ; only breast, and underparts white. Bill, legs, and bare space round eye red; irides reddish brown.

Young. Dark parts brownish black without gloss; bill and legs olivegreen; feathers of head and neck tipped with buffy white. Length 39-40 inches. 


\section{PLATALEID正.}

195. White Spoonbiru. Platalea leucorodia, Linnæus. On migration, Europe and mostly in S.E. of England, where it formerly bred.

White; lower neck and the short bushy crest tinged with yellow; bill N. Africa, black at base, yellow and broadly fiattened at the end; chin bare and India, and yellow ; iris dull red. Length 32-36 inches.

Ceylon.

Young. Without crest or yellow skin; bill blackish ; iris black.

\section{B I D I D 尼.}

196. Glossx Ibis. Plegadis falcinellus (Linnæus). Irregularly on migration.

Bill long, curved down (as in Curlew); face bare; general colour chestnut-brown; the back much glossed with green and purple; legs greenish grey. Length 22 inches.

\section{Order ODONTOGLOSS 床.}

\section{Family PHCEICOPTERIDE.}

197. Flamirgo. Phoenicopterus roseus, Pallas. Four occurrences, possibly escapes.

Bill bent down in the middle; general colour rosy white; primaries black; rest of wings, both above and below, deep rosy pink; the very long legs and webbed feet pink. Length 60-70 inches.

\section{Order AN SERES. Family ANATID必.}

198. GreY-LAG Goose. Anser cinereus, Meyer. Breeds in north of Scotland and Hebrides, wandering southward from autumn to spring.

Rump and wing-coverts ashy grey; bill flesh-colour; nail white; legs and feet flesh-coloured.

Adult. White round base of bill; breast with a few black marks. Length 35 inches.

199. White-fronted Goose. Anser albifrons, Scopoli. Visitor, late in autumn to spring.

Much smaller than preceding; bill orange-yellow; nail white; legs and feet orange-yellow.

Aclults. White round base of bill ; much marked with black on breast, most so in male.

Young. Without black on breast, and in first plumage without white round bill ; bill and feet paler than in adult, and nail of bill brownish black, pale at the tip. Length 27 inches.

A smaller race, with markings more defined, is known as the Lesser White-fronted Goose, A. erythropus, and a young bird of this race was obtained in Northumberland, September 16th, 1886.

S. Europe,

S. Asia, Africa.

Asia, passing

S. in winter.
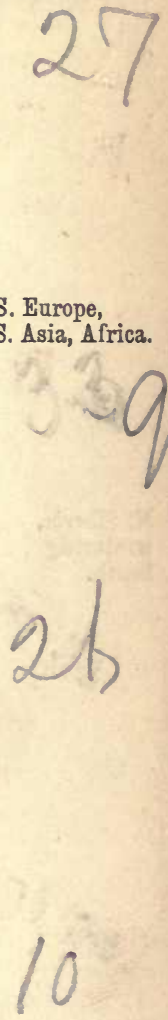
200. Bean-Goose. Anser seyetum (J. F. Gmelin). Autumn to spring.

No black on breast; bill blackish brown, nail black; legs and feet orange-yellow. Length 34 inches.

201. Pink-Footed Goose. Anser brachyrhynchus, Baillon. Autumn to spring, chiefly in E. of England ; not yet obtained in Ireland.

Much as last, but smaller; nail of bill black; legs and feet fleshcolour. Length 28 inches.

N.W. America. 202. Svow Goost. Chen hyperboreus (Pallas). First obtained in Ireland in 1871, and since noticed several times.

Adults. White; primaries black ; bill, legs, and feet red.

Young. Head, neck, back, and breast pale slate-grey; scapulars and wing-coverts darker with pale edges, otherwise white; bill blackish. Length 23 inches.

203. Brent Goose. Bernicla brenta (Pallas). Winter visitor on sea-coasts in Gt. Britain, chiefly on the east side.

Head, neck, and throat black, with a small white patch on each side of neck. Length $23-24$ inches.

204. Bernacle Goose. Bernicla leucopsis (Bechstein). Winter visitor on sea-coasts in Gt. Britain, chiefly on the west side.

Head, neck, and throat black; front and sides of head and upper throat white; black mark between eye and bill. Length 25 inches.

N. Siberia, wintering South.

205. Red-BReasted Goose. Bernicla ruficollis (Pallas). Very rare winter straggler. Not observed in Ireland.

Fore part of chest and sides of neck brick-red; white patch between eye and bill. Length 22 inches.

206. Mute Swan. Cygnus olor (J.F. Gmelin). Chiefly semi-domesticated bird. Winter visitor.

Adults. White; bill yellow, with black tubercle above nostrils*.

Young. Greyish brown; bill lead-coloured. Length 60 inches.

207. Whooper Swan. Cygnus musicus, Bechstein. Winter visitor.

White; bill, basal part to below nostrils yellow, the rest black.

Young. Greyish brown; bill flesh-colour. Length 60 inches.

208. Bewick's Swan. Cygnus bewicki, Yarrell. Irregular w. v.

Much smaller than last; bill, basal part, but not below nostrils, yellow, the rest black, and the ridge of upper mandible black throughout its length.

Young. As in preceding species.' Length $46-50$ inches.

* The so-called "Polish Swan" is now generally admitted to be a mere variety of the Mute Swan, which sometimes has white cygnets. 
209. SHELd-Drake. Tadorna cornuta (S. G. Gmelin). Resident.

Male. Head and neck green, below that a white collar, with a broad rich chestnut band, covering the breast; wing-coverts white; wing-spot or speculum, formed by colours of the outer webs of the secondaries, green; fleshy knob on base of upper mandible; bill red; legs and feet pink.

Female. Smaller than male; less bright markings, and no knob on bill. Length 25-26 inches.

210. RUDDY SHELd-DRAKE. Tadorna casarca (Linnæus). Of rare occurrence; introduction may be sispected.

General colour rufous buff; crown light buff; wing-coverts white; wing-spot green; bill, legs, and feet blackish.

Sexes alike, except that male has a blackish ring round neck. Length 25 inches.

211. Wild Duck (Mallard, male). Anas boscas, Linnæus. Resident. Sexes differ in plumage.

Wing-spot purple; tail of sixteen feathers; bill rather longer than head.

Male. Head and neck green; four central tail-coverts black, lengthened and curled upwards.

Female. General colour brown.

Male in summer. Resembles female. Length 21 inches.

212. Gadwall. Anas strepera, Linnæus. Chiefly autumn to spring, 4 but now breeds in Norfolk, and doubtless elsewhere.

Wing-spot white; bill shorter than head, and narrowing slightly towards tip. General colour grey.

Male. Chestnut on shoulder of wing.

Female. Brown and grey. Length 20 inches.

5 213. Shoveler. Spatula clypeata (Linnæus). Resident.

Bill broadly dilated at the end, being twice as broad near the tip as at the base ; wing-spot green.

Male. Head and neck green; shoulders pale blue; iris yellow.

Female. Dark brown.

Male in summer. Resembles the female. Length 20 inches.

\section{6}

214. Prntatl. Dafila acuta (Linnæus). Autumn to spring; occasionally nesting in Ireland.

Tail graduated, of sixteen feathers, two centre feathers much elongated in male, slightly so in female; wing-spot dark green, glossed with copper; bill as long as head.

Male. Head, cheeks, chin, sides of neck, and upper neck in front rich dark brown; two centre tail-feathers black.

Female. Brown above, greyish white below. Length 24-28 inches.

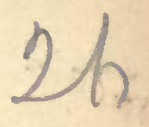

Mediterranean region, S. Russia, S. Asia.
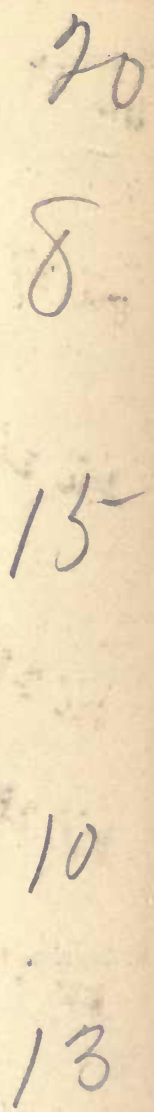


\section{Teas. Querquedula crecca (Linnæus). Resident.}

Wing-spot black and green; tail of sixteen feathers.

Male. Head and neck chestnut, with broad green stripe from eye down sides of neck, margined on sides of head with buff.

Female. Above dark brown, feathers edged with grey; below whitish. Length 13-15 inches.

N. America.

216. AMERICAN GREen-winged TEAL. Querquedula carolinensis (J.F.Gmelin). Three records: Hants ; Yorkshire, 1858; Devon, 1879.

Male. Very like last, but has uniform slate-grey scapulars and broad white crescent on each side of breast in front of shoulder.

Female. Not to be distinguished from that of Q. crecca.

N. America.

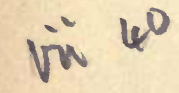

217. American Blue-winged Teal. Querquedula discors (Linnæus). One occurrence in Dumfriesshire, 1858.

American representative of our Garganey.

Both sexes. Wing-spot green; shoulder britliant light blue.

Male. White crescentic patch in front of eye.

218. Garganex, or Summer Teat. Querquedula circia (Linnæus). Spring to autumn on east side; rare in Ireland.

Male. Wing-spot green, between two bars of white; wing-coverts or shoulders bluish grey; neck and breast dark brown, with pale brown crescent-shaped bands.

Female. Much as female of $Q$. crecca, but without green metallic speculum; shoulders with very slight grey tinge. Length 15-16 inches.

219. Wigeon. Mareca penelope (Linnæus). Chiefly autumn to spring, but a number breed in north of Scotland.

Tail of fourteen feathers ; bill shorter than head.

Male. Forehead and crown buffish white; wing-coverts white; back white finely vermiculated with black; wing-spot green.

Female. Above brown and greyish brown; head and neck mottled with light brown and blackish brown; shoulders of wings greyish white; wing-spot greyish.

Males in summer lose the whitish crown, and to a certain extent resemble the females. Length 20 inches.

N. America. 220. American Wigeon. Mareca americana (J. F. Gmelin). One from Leadenhall Market in 1837-8.

Much like last, but larger, and male with green stripe on side of head, from eye to neck; head and neck whitish, with black specks.

Female. Head and neck yellowish white, speckled with black.

S. Europe,

N. Africa,

Persia, win-

tering in India.

221. Red-crested Pochard. Fuligula rufila (Pallas). Scarce straggler.

Wing-spot white; tail of fourteen feathers, as in next four species.

Male. Head and upper neck reddish chestnut; feathers on crown 
forning an erectile crest; back yellowish brown; lower neck, breast, and belly black; bill and legs vermilion; iris red.

Female. Crown dark brown without crest; cheeks, neck, and sides of throat light grey; bill and legs reddish brown. Length 21 inches.

222. Pochard, or "Duv-BIRd." Fuligula ferina (Linnæus). Chiefly autumn to spring, but breeds in a few localities.

Wing-spot grey; bill black, longer than head, broad band of blue across the middle.

Male. Head and neck chestnut-red; breast and upper back black; back and scapulars white, finely vermiculated with black; iris red.

Female. Markings as in male, but with dull brown head and neck; dark brown breast and upper back. Length 17-19 inches.

223. White-eyed Pochard. Fuligula nyroca (Güldenstädt). Casual visitor in cold winters.

Wing-spot white; tail short, of fourteen feathers, much graduated; bill lead-coloured, longer than head.

Male. Head, neck, and general colour above chestnut-brown; underparts greyish white; iris white.

Female. Marked as male, but duller; iris dull white. Length 15-17 inches.

7 224. TuFted Duck. Fuligula cristata (Leach). Chiefly from autumn to spring, but breeds in a good many localities.

Wing-spot white.

Male. Head and neck glossy purplish black, with an occipital crest or tuft ; breast, belly, sides, flanks, and speculum white ; the rest of plumage black; iris yellow.

Female. Crest smaller; brown where black in the male; underparts brownish white. Length 17 inches.

\section{Scadp. Fuligula marila (Linnæus). Autumn to spring.}

Wing-spot white; bill very broad, about as long as head.

Male. Head, neck, upper breast, rump, and under tail-coverts black, with green gloss; back and scapulars white, broadly vermiculated with black; belly white ; iris straw-yellow.

Female and young male. White band round base of bill, brosdest in female; head and neck dark brown, as are all the parts which are black in the male. Length 18 inches.

226. Goldeneye. Clangula glaucion (Linnæus). Autumn to spring. Bill much shorter than head; tail of sixteen feathers, as in next.

Male. Head and neck glossy green; feathers on crown slightly lengthened; small white spot at base of bill; scapulars white; wingspot white.

Female and young male. Head and neck ash-brown; no white spot on head; wing-spot white, divided by a black line. Length 16-19 inches.

Northern.

\& S. Europe,

N. Africa, Asia,

S. in winter.
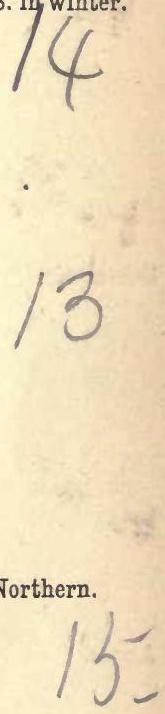

Sub-arctic or Northern.

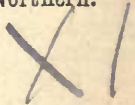


N. America.
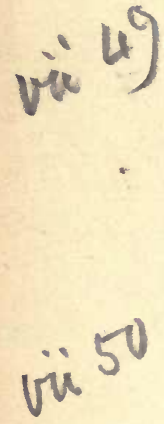

Sub-arctic.
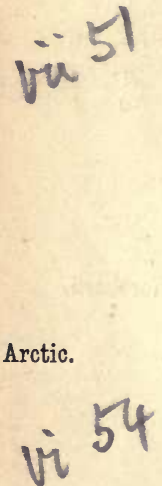
Norfolk, Feb. 1830 ; Yorkshire, August 1845.

Male. Head and back of neck white; line across forehead, spot between bill and eye, and patch on nape green. Wing-spot purple between two white bars.

Female. General colour rufous brown, crossed with short black bar's below; wing-spot bluish black. Length 18-20 inches.

Arctic America, Greenland.

227. BUfFel-Headed Goldeneye. Clangula albeola (Linnæus). Four occurrences in Gt. Britain at long intervals.

Wing-spot as in last.

Male. Head and throat glossy bluish black; large white patch forming an erectile crest behind round nape; scapulars white; wing-spot white.

Female. Head and neck ash-brown, with same white patch on head: Length $14-15$ inches.

228. Long-TaIled DuCK, or " Calloo." Harelda glacialis (Linnæus). Autumn to spring; doubtless breeds sparingly in the Shetlands.

Tail of fourteen feathers; bill much shorter than head, slightly narrowing and rounded towards the tip; axillaries brown.

Male in summer. Forehead, fore crown, and sides of head sooty grey; space round eye whitish; throat, neck, and breast black; back black, margined with rufous.

Male in winter. Scapulars white; rump black. Two centre tail-feathers black, and about five inches longer than the rest, which are white. Length 17 inches.

Female, summer. Greyer than in winter.

Female, winter. Crown and chin dark brown; sides of head dull white, patch on each side of neck dark brown; tail not elongated. Length 16 inches.

229. Harlequin Duck. Cosmonetta histrionica (Linnæus). Very rarely in winter.

Bill much shorter than head, and Goose-shaped; a small lobe on each side of the mandible; tail much graduated.

Male. General colour dull blue; head and neck blackish blue; rusty red stripe from eye to nape, with white line above; flanks chestrutred; white marks across breast. Wing-spot purple. Length 17 inches.

Female. General colour brown above; below whitish; white patch on forehead, and white spot behind eye. Wing-spot bluish black. Length 14 inches.

230. STELLER's Eider. Somateria stelleri (Pallas). Two occurrences :

231. King Eider. Somateria spectabilis (Linnæus). Rarely, in winter.

Central line of feathers on the upper mandible running down to nostrits.

Male. Crown bluish grey, sides of head below eye pale green; black stripe on throat, meeting at chin; scapulars black. 
Female. Brown; feathers on back marked with dark brown. Length 24 inches.

232. Common Erder. Somateria mollissima (Linnæus). Resident from Coquet Island northwards. Not breeding on Irish coasts.

Central line of feathers on upper mandible only reaching halfway to nostrils.

Male. Crown of head black; nape green; scapulars and inner secondaries white.

Female. As in King Eider, but darker. Length 25 inches.

233. Scoter, or Black Duck. Edemia nigra (Linnæus). Chiefly autumn to spring, but a few breed in north of Scotland.

Adult male. Entirely black; bill black, with centre of upper mandible yellow, and a knob at the base.

Female. Sooty brown; chin and throat whitish; side of head greyish white; bill without knob.

Young. Cheeks, chin, sides, and front of neck dull greyish white; belly speckled with brown and white. Length 21 inches.

234. Velvet Scoter. Edemia fusca (Linnæus). Autumn to spring. Adult male. Velvet-black, except the large wing-spot, eyelid, and patch below eye, which are white; iris yellowish white.

Female. Blackish brown, but with white wing-spot. Length 21 inches.

235. Surf-Scoter. Edemia perspicillata (Linnæus). Autumn to N. America. spring.

Adult male. Black; white patch on nape and white patch on forehead; legs and feet orange-red.

Female. Brownish black; white patch only on nape. Length 21 inches.

The following-Mergansers, or "Saw-bills"-have the bill slender and straight, its edges with strong saw-like teeth pointing backwards.

236. Goosander. Mergus merganser, Linnæus. Chiefly on fresh water from autumn to spring, but a few breed in Scotland.

Male. Head and upper neck glossy metallic black, slightly crested; lower neck and underparts white ; rump and tail ashy grey ; bill bloodred, and, as in next two, longer than head; iris red.

Female. Head and upper neck light chestnut, crested; above slategrey; below white; wing-spot white.

Young. Like female, but without crest. Length 26 inches.

237. Red-Breasted Merganser. Mergus serrator, Linnæus. Resident in Scotland and Ireland; elsewhere from autumn to spring.

Male. Head and neck glossy metallic black; crest of narrow elon31 gated black feathers; white collar on neck, showing much when flying; 
rump white, with wavy black lines; tail uniform brown; bill vermilion; legs orange; iris red.

Female and young. Like those of preceding species, but much smaller, and head darker, black bar across wing-spot. Length 22-24 inches.

N. America. 238. Hooded Merganser. Mergus cucullatus, Linnæus. Very rare straggler, chiefly to Ireland.

Male. Head and neck black, with an erectile rounded crest; the back part white, with a black edge forming a hatchet-shaped mark with the edge outwards; legs dull red. Length 19 inches.

Female and young male. Head, neck, back, and wings dark brown; crown reddish brown; feathers elongated. Length $17 \frac{1}{2}$ inches.

239. SMEw. Mergus albellus, Linnæus. In winter months.

Male. Bill shorter than head. Black, grey, and white. Head and neck white; black stripe through eye to nape; slightly crested; rump ashgrey.

Female. Head and nape chestnut, crested; above slate-grey; black patch from bill to eye; rump greyish black.

Young male. Like female, but has no black patch between eye and bill. Length 14-17 inches.

\section{Order C O L U M B 屆. Family C O L U M B I D A世.}

240. Ring-Dove, or Wood-Pigeon. Columba palumbus, Linnæus. Resident.

Iv 39 neck.

Adult. White on outer wing-coverts; white patch on each side of

Young. Without white patch on neck. Length 16-17 inches.

241. Stock-Dove. Columba cenas, Linnæus. Resident, breeding in holes in trees and cliffs both on coast and inland, and in rabbitburrows, \&c.

Adult. Sides of neck with metallic green patch; axillaries grey.

Young. Without patch on neck. Length 13 inches.

242. Rock-Dove. Columba livia, J. F. Gmelin. In caves, on sencoasts, and also in ruined buildings; chiefly in Scotland and Ireland. Very rare on the coasts of England.

Lower back and mump white; two conspicuous black bands across the wings; axillaries white. Length 13 inches.

243. Turtie-Dove. Turtur communis, Selby. Spring to autumn.

Head, nape, rump, and outer wing-coverts bluish ash ; under tailcoverts white; collar-patch of four rows of black feathers tipped with white on each side of neck; tail graduated, two centre feathers brown, the rest slate-grey, the ends and outside web of outer pair white.

Young. Without neck-patch. Length $11 \frac{1}{2}$ inches. 
244. Eastern Turtue-Dove. Turtur orientalis, Gray. Young bird reported once from Yorkshire (P. Z. S. 1890, p. 361).

Eastern representative of last and rather larger, darker ; collar-patch and tail ashy, where white in Common Turtle-Dove. Length 13 inches.

\section{Order PTEROCLETES. Family PTEROCLID}

245. Three-toed Sard-Grouse. Syrrhaptes paradoxus (Pallas). Steppes of Not recorded till 1859. Vast flights in 1863, and again in 1888, C. Asia, when, and in 1889 , a few pair bred.

Legs and toes feathered to the claws; no hind toe. Length $16 \frac{1}{2}-20$ inches.

Male. On breast whitish band margined with black; two centre tailfeathers $3 \frac{1}{2}$ inches longer than the others.

Female. Blackish band on throat; tail-feathers shorter; above more marked with black than male.

\section{Order GALIIN 无。 Family TETRAONID正.}

246. Capercatluite. Tetrao urogallus, Linnæus. Exterminated in eighteenth century ; re-introduced in 1837, to Scotland, and now common in fir-woods, especially in Perthshire.

Mate. General colour dark slaty grey; breast glossed with green. Length 36 inches.

Female. Much like Grey-hen, but larger. Length 26 inches.

247. Black Grouse. Tetrao tetrix, Linnæus. Resident in Great Britain ; not indigenous in Ireland.

Black-cock, male. Axillaries, under wing- and tail-coverts, and bar across wing white; rest of plumage glossy black; outer tail-feathers curving outwards. Length 22 inches.

Grey-hen, female. General colour chestnut and buff, barred and marked with black. Length 15 inches.

248. Red Grouse. Lagopus scoticus (Latham). Resident: peculiar to the British Islands.

Primaries dark brown; tail of sixteen feathers, as in next.

Male. Dark brown, with large scarlet wattle above eyes.

Female. Lighter and smaller, with very small wattles. Length 14-15 inches.

249. Ptarmant. Lagopus mutus (Montin). Resident on high mountains in Scotland.

Primaries white, with black shafts.

Male in summer. Black above, finely marked with brown and white on lower back and rump; wings and underparts white; scarlet wattle above eyes.
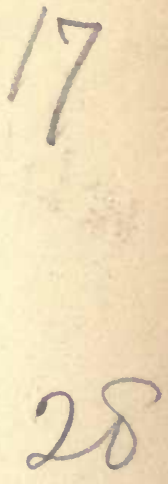
Female in summer. Above buff, barred and closely marked with black lines and white tips to feathers.

Autumn. Above slate-grey, finely marked with black; head and neck marked with rufous brown.

Winter. Entirely white, except the black tail with white tips; the male only having black between eye and bill, and black stripe behind eye. Length 15 inches.

\section{PHASIANID无.}

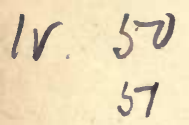

IV 52
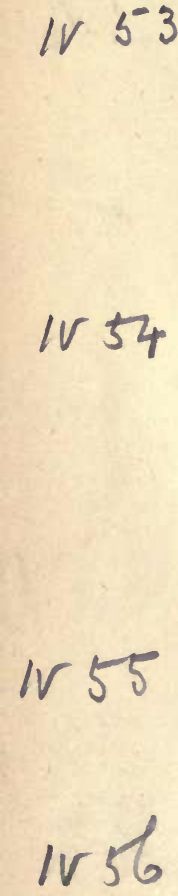

\section{Pheasant. Phasianus colchicus (Linnæus). Resident.}

The pure $P$. colchicus, without white ring, is seldom seen now, as the Chinese $P$. torquatus has interbred.

\section{Partridge. Perdix cinerea, Latham. Resident.}

Adult. First primary rounded at end ; legs bluish grey.

Young. First primary sharp at the end; legs light brown.

Female. Both old and young have feathers of wing-coverts darker than in male, and barred with buff on each side of the web. Length $12 \frac{1}{2}$ inches.

252. Red-LegGed Partridge. Caccabis rufa (Linnæus). Resident; chiefly in the east and south of England. Introduced about 1770, and gradually spreading.

Sexes alike, except that male has knobs or blunt spurs on legs. Black gorget or collar from bill through eyes, enclosing a white throat; dirty white below this collar, spotted and streaked with black; bill, eyelids, and legs red; tail chestnut, of fourteen feathers. Length 14 inches.

253. QJarL. Coturnix communis, Bonnaterre. Spring to autumn; rare in winter.

General colour buff, marked much as Partridge above.

Male. Chin and throat blackish.

Female. Chin and throat buff; larger than male. Length 7 inches.

\section{Order FULICARIÆ. Family RALIID E.}

254. Corn-Crake, or Land-Rarl. Crex pratensis, Bechstein. Spring to autumn, rarely in winter.

General colour above brownish buff, each feather on back with a black centre; axillaries chestnut; bill shorter than head-as in the three following species. Length $10 \frac{1}{2}$ inches.

255. Spotted Crake. Porzana maruetta (Leach). Spring to autumn.

General colour above olive-brown; each feather on back with blackish centre, and spotted with white; axillaries barred with white; breast spotted. Length $8 \frac{1}{2}$ inches. 
256. Batllon's Crake. Porzana bailloni (Vieillot). Rare. Spring Europe, to autumn. Has nested in Eastern counties.

Above dark reddish brown, marked with black; cheeks, throat, and Africa, S. Asia. breast slaty blue; flanks black, barred with white; more white streaks and spots on back than in next species; under wing-coverts mottled with whitish.

Young. Chin and throat white; breast and belly buff. Length 7 inches.

257. Litmle Crake. Porzana parva (Scopoli). Scarce. Spring to autumn.

Much like last, but larger, and with flanks slate-grey; white spots only on centre of back ; under wing-coverts uniform. Length 8 inches.

258. WATER-RAIL. Rallus aquatious, Linnæus. Resident.

Bill reddish at base, longer than the head, and slender.

Above brown, blotched with black; below slaty blue; axillaries, belly, and flanks black, barred with white; legs and feet brown. Length 10 inches.

259. Moorhev, or Waterhen. Gallinula chloropus (Linnæus). Resident.

General colour above olive-brown, below greyish black; scarlet frontal plate in adult, greenish brown in the young; legs and feet greenish. Length 13 inches.

260. Cooт. Fulica atra, Linnæus. Resident.

Front toes with rounded lobes.

General colour slaty black; secondaries tipped with white, forming a wing-bar; broad white shield on forehead; legs bluish grey; iris crimson. Length 16 inches.

\section{Order ALECTORIDES. Family GRUID无.}

261. Crane. Grus communis, Bechstein. Rare straggler. plumes.

General colour slate-grey; tertials bluish black, forming elongated

Adults with a red warty patch on crown. In young this is absent, and the grey feathers on back are mixed with brown. Length 48 inches.

Europe and

N. Asia, wintering in S. Europe,

N. Africa, and S. Asia.

262. Demoiselle Crane. Grus virgo (Linnæus). Recorded from the Orkneys.

General colour bluish grey, sides of the head, throat, neck, the lengthened pointed feathers on upper breast, and quill-feathers black; from each eye a tuft of lengthened white feathers extending backwards.

S. Europe, N. Africa, and N. Asia, wintering in C. \& S. Africa and India. Length 30 inches. 


\section{OTIDID无.}

(No hind toe.)

Europe, rarely in $\mathrm{N}$. Atrica, Central Asia.

S. \& C. Europe, N. Africa.

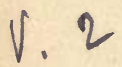

S.W. Asia to N. India.

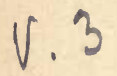

S. Europe and N. Africa, wintering in S. Africa.

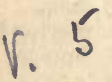

263. Great Bustard. Otis tarda, Linnæus. Extinct as a resident since about 1838 : now an irregular visitor.

Male. Head bluish grey; general colour above reddish buff, with blackbands on each feather ; wings white or greyish, except the dark primaries; tuft of long bristly white feathers from base of bill; band of rich chestnut across breast, with grey band underneath, below this white.

Female and young male. Without bristles on throat or band on chest, and back more banded with black. Length: male 45 inches, female 36 .

264. Littrle Bustard. Otis tetrax, Linnæus. Rare visitor: chiefly to England in autumn.

Male in spring till August. General colour above sandy brown; throat and cheeks bluish black, with two white gorget-marks across.

Adult male. Back vermiculated with black, but otherwise in winter resembles the female.

F'emale. Back spotted or blotched with black on sandy-brown groundcolour ; underparts white; iris golden yellow. Length 16-17 inches.

265. Indian Houbara Bustard. Otis macqueeni, J. E. Gray. One occurrence in Lincolnshire, 1847; several in Belgium, \&c.

Male. Above finely vermiculated with black on a light buff ground; crest of white feathers tipped with black; black ruff on sides of neck, with a few pied and white feathers on the lower part; tail with three bluish bars.

Female. Like male, but crest and ruff smaller. Length 28-30 inches.

\section{Order IIIIICOL 妮. Family GLAREOLID无.}

266. Pratincole. Glareola pratincola (Linnæus). Irregular straggler on migration.

Axillaries chestnut-red; tail much forked.

Above dull brown; rump and tail-coverts white; throat buff, bordered by a black line meeting at the gape, forming a bridle or collar; wings very long, about $7 \frac{1}{2}$ inches. Length $9-10$ inches.

\section{CHARADRIID E.}

(Hind toe absent in most species.)

267. Thick-knee, or Stone-Curlew. Edicnemus scolopax (S. G. Gmelin). Spring to autumn; some remain in Devon and Cornwall through the winter.

Two obscure white bands across (extended) wings; breast streaked; 
chin and throat white; tail rather long and graduated; bill yellow; terminal half black; legs yellow; iris very large and yellow. Length 16 inches.

268. Cream-coloured Courser. Cursorius gallicus (J. F. Gmelin). An irregular, but not very rare straggler to England; once to S. Scotland; not recorded from Ireland.

General colour sandy buff; primaries and primary-coverts black; Punjab. axillaries black; bill as long as head, slightly curved; legs greyish white. Length $9 \frac{1}{2}-10$ inches.

269. Golden Plover. Charadrius pluvicllis, Linnæus. Resident.

Male in spring. Above blackish, spotted with yellow; chin, throat, breast, and belly black *.

Female. Less black below, being mottled with white feathers.

In winter. Below white, chest and flanks marked with brown. Axillaries white. Length 9 inches.

270. Asratic Golden Plover. Charadrius fulvus, J. F. Gmelin. A rare or seldom recognized straggler.

Axillaries smoky grey; otherwise as last, but slightly smaller.

271. Grex Plover. Squatarola helvetica (Linnæus). Autumn to spring.

Axillaries black; small hind toe present.

In spring. Above white, barred with black; underparts black, or black marked with white.

In winter marked much as Golden Plover, but the yellow spots of that species are replaced by white, young birds only being marked with a few yellow spots. Length 10-12 inches.

272. Dotrerex. Eudromias morinellus (Linnæus). Spring to autumn. Mountains of Cumberland and Westmoreland, and of Scotland; elsewhere only on passage in spring and autumn.

Axillaries greyish. Crown nearly black with white lines below, all round above eyes to bill; chin and throat white ; upper breast chestnutred; belly black.

Females brighter than males. Length 9 inches.

273. Rivged Plover. Agialitis hiaticula (Linnæus). Resident.

Above hair-brown; forehead white; fore crown black, reaching to and below eyes on each side, and to base of bill and ear-coverts; throat white, forming a complete ring, below this a broad black band round breast; both these collars narrowing to a line round nape; rest of underparts white ; eyelids, legs, and feet orange; basal half of bill yellow, rest black.

* I have seen birds with black markings beginning to show as early as 7 th January, and remaining as late as 20 th September. 
Females have the collars less clearly defined.

Young brown where black in adults ; bill black; legs brown. Length $7-7 \frac{1}{2}$ inches.

Individuals belonging to a small race have often been recorded as the next species.

Europe,

Asia,

N. Africa.

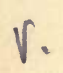

Caspian Sea to S. Africa.
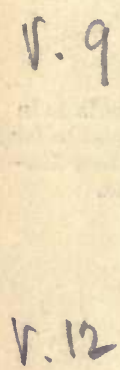

N. America.
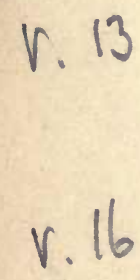

274. Litrle Rivged Plover. AEgialitis curonica (J. F. Gmelin). An extremely rare straggler, though common not far off on the Continent.

Resembles last, but much smaller, is a more inland bird, and has shaft of first primary white; eyelids golden yellow; legs and feet pale brown. Length $6 \frac{1}{4}$ inches.

275. Caspian Plover. Aggialitis asiatica (Pallas). One occurrence: Great Yarmouth (P.Z. S. 1890, p. 461).

Lores pure white; legs pale clayey yellow; axillaries white.

Male in summer. Above hair-brown; forehead, throat, lores, stripe above eye, and underparts white; lower throat and breast with band of chestnut, bordered below with black.

Female. Paler; breast-band nearly colour of back.

Male in winter. Like female in summer, but breast-band paler and indistinct.

276. Kennish Plover. Agialitis cantiana (Latham). Spring to autumn ; breeding in Kent, Sussex, and Channel Islands.

Bill and legs black.

Male. Above hair-brown; forehead white, black patch on fore crown; rest of crown and nape buff: black line through eye from bill to earcoverts; a black patch on each side of breast, not forming a collar; rest of underparts white.

Female. No black on fore crown, but that and crown uniform with the back; the patch on each side of breast same colour as back. Length $6 \frac{1}{2}$ inches.

277. Killdeer Plover*. Egialitis vocifera (Linnæus). Two occurrences: Hants, 1857; Scilly Is., Jan. 1885.

Two black bands across chest; rump and upper tail-coverts chestnutluff; tail rather long and wedge-shaped. Length 10 inches.

278. Peewit, Lapwing, or Green Plover. Vanellus vulgaris, Bechstein. Resident.

Hind toe present and well developed.

A bove glossy green; crown, throat, and breast black; crest of long slender black feathers; upper and under tail-coverts rufous; legs fleshcoloured.

Young. Crest short; feathers above with buff edges; legs dark broxn. Length 13 inches.

* Properly " Killdee," from the note (Audubon). 
279. Soctabie Lapwivg. Vanellus gregarius (Pallas). One (immature) record : Lancashire, 1860.

Secondaries entirely white; shortest primaries black on the outer webs and white on the inner webs; hind toe present. Length 13 inches. $A d u l t$. Crown black, bordered below by a broad white stripe above eye to nape ; belly black, bordered below with chestnut to the vent.

Young. Crown dark brown; band from forehead to nape buffish white; breast white, marked with dark brown.

280. Orster-catcher. Hamatopus ostralegus, Linnæus. Resident.

No hind toe ; bill yellow, longer than head.

Plumage black and white; head, neck, scapulars, and terminal half of tail black; rump, upper tail-coverts, and axillaries white; legs pink; eyelids crimson. Length 16 inches.

281. TuRnstone. Strepsilas interpres (Linnæus). Autumn to spring; not yet detected breeding in British Isles.

Hind toe present; bill black, strong, straight, and pointed, shorter than head; chin and throat pure white.

In spring. Back and wings marked with chestnut and black; lower back and rump white, the latter crossed by a black band; legs and feet orange-red.

In winter, chestnut colour absent; legs pale red. Length $9 \frac{1}{2}$ inches.

\section{SCOLOPACID E世.}

282. Arocet. Recurvirostra avocetta, Linnæus. Formerly bred in S. and E. of England, now only occurs on migration.

Bill black, curved upwards and pointed.

White, except crown to below eye, hind neck, primaries, and some of the inner secondaries and wing-coverts, which are black; legs and the partially webbed feet light blue; iris red.

Young. Crown and hind neck brown. Length 18 inches.

283. BuAcK-wivged Stilt. Himantopus candidus, Bonnaterre. Ir- S. Furope and regular wanderer on migration.

Bill black, twice as long as head, slender, straight, and pointed; hind Asia, to in winter toe absent; nape, upper hind neck, wings, and back black; underparts white ; legs pale pink, about $4 \frac{1}{2}$ inches long.

Old males have pure white heads. Length 13 inches.

284. Grex Phalarope. Phalaropus fulicarius (Linnæus). Of irregular appearance late in autumn to spring. Sometimes in great numbers in autumn.

Front toes as in next species lobed, like a Coot.

Bill short and wide; tail graduated.

In summer. Below chestnut.

In winter. Forehead and crown white; grey nape, white wing-bar; below white. Length 8 inches.

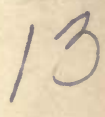

S. Africa. 
285. Red-Nraked Phalarope. Phalaropus hyperboreus (Linnæus). Spring to autumn, a few nesting in some parts of N. Scotland. One record from Ireland in winter.

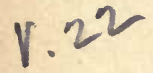

Bill short, about an inch long, thin, and tapering to a point; inside of upper mandible smooth, not laminated as in most Scolopacidæ.

Females larger than males, and brighter.

In spring. Chin and throat white; bright rufous patch on each side of neck extending almost across the throat.

In winter. Crown brown; scapulars blackish, each feather edged with brownish buff. Length 7 inches.

$231^{24}$ accession in winter. Scolopax rusticula, Linnæus. Resident: large

Feathers on breast barred; sixteen tail-feathers with silvery-white tips on underside; greyish tips above. Length 13 inches.

287. Great or Solitari Snipe. Gallinago major (J. F. Gmelin). On passage in spring and autumn, seldom later than September.

Belly barred to the vent; sixteen tail-feathers, lower half of the four outside pairs white in adults, white with brown bar in young. Length $11 \frac{1}{2}$ inches.

288. Common Snipe. Gallinago coelestis (Frenzel). Resident.

627 Axillaries white, barred with blackish grey; tail-feathers fourteen. Length $10 \frac{1}{2}$ inches. "Sabine's Snipe" is merely a dark variety.

289. JАOK SNIPe. Gallinago gallinula (Linnæus). Autumn to spring.

Purple gloss on back; axillaries white; tail-feathers twelve, centre pair longer than the rest. Length $7 \frac{1}{2}$ inches. Never known to breed in British Islands.

N. America, wintering in Brazil and Chili.

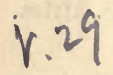

290. Red-Breasted Snipe. Macrorhamphus griseus (J. F. Gmelin). Very rare straggler, generally in autumn.

Bill Snipe-like, about $2 \frac{1}{2}$ inches long; front toes webbed at base, most so between middle and outer toes; shaft of first primary pure white.

Rufous below in summer (when not seen in British Islands); white in winter, when the general colour above is ash-grey; lower back white; rump white, barred with black. Length $8 \frac{1}{2}$ inches.

Ssandinavia, N. Russia, wintering in Egypt, S. Asia, Philippines, and Madagascar.
291. BROAD-BILLED SANDPIPER. Limicola platyrhyncha (Temminck). Rare visitor on migration; not yet in Scotland.

Bill much longer than head, nearly as broad as high at the base, very flat and wide up to the tip, with blunt rounded points. Very little or no white on secondaries and upper tail-coverts; legs greenish black.

Winter. Ashy grey above, each feather with a dark centre Length $6 \frac{1}{2}$ inches. 
292. Sanderling. Calidris arenaria (Linnæus). Autumn to spring. Arctic breeder.

Legs and bill black; bill as long as head and straight; no hind toe.

In spring. Upper parts rufous and black; head, throat, and upper breast rufous, marked with black.

In winter. Grey above, white below; rump ashy grey; as long as the head. Length 8 inches.

293. CuRLEW-SANDPIPER. Tringa subarquata, Güldenstädt. On passage in spring and autumn.

Bill curved downwards; rump white.

In spring. General colour dark reddish chestnut, marked above with blackish.

In autumn. General colour grey above; below white. Length 7 inches.

No authentic eggs of this species are known.

294. Кгот. Tringa canutus, Linnæus. Autumn to spring.

Bill black, quite straight, longer than head.

Plumage changes much as in last, but the red is not so dark; rump and upper tail-coverts whitish, barred with blackish; legs and feet black. Length 10 inches.

Young. Feathers on back bordered with dark bars, tipped with buffy white; below tinged with buff; legs and feet yellowish green.

Authentic eggs of the Knot are unknown.

295. Duxlrv. Tringa alpina, Linnæus. Resident: large accessions in cold weather.

Bill very slightly bent down towards the tip and longer than head; bill, legs, and feet black.

Summer. Belly black; general colour above reddish brown, marked with black.

Winter. Belly white. General colour above ashy grey. Length 8 inches.

296. Purple SANdpiper. Tringa striata, Linnæus.

Autumn to Sub-arctic. spring; not yet proved to breed in British Islands.

Bill as in Dunlin, but base dull yellow.

Rump and upper tail-coverts nearly black, with a purplish tinge; seventh to ninth secondaries nearly white; legs rather short and dull yellow. Length 8 inches.

Young have feathers above with white margins.

297. Temminck's Stivt. Tringa temmincki, Leisler. Irregular visitor on migration.

Bill straight; legs and feet greenish brown.

Outer tail-feathers pure white. Length $5 \frac{3}{4}$ inches.

298. Litrte Stivt. Tringa minuta, Leisler. On passage in spring and autumn.

Plumage above much as in Dunlin both in summer and winter, but bill quite straight.

Outer tail-feathers ashy brown; legs and feet black. Iength 6 inches.
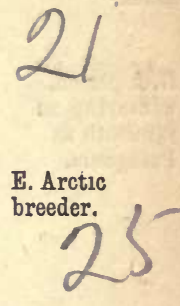

W. Arctic
breeder.
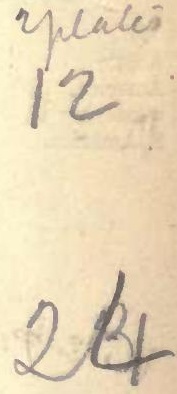

N. Europe and Asia, wintering in Africa and India.

N.E. Europe Asia, wintering southward 
Arctic America, wintering south.

$v .3$

N. America, wintering as far south as Patagonia. wintering in S. America and Falkland

Islands.

Arctic

America, wintering in

S. America.
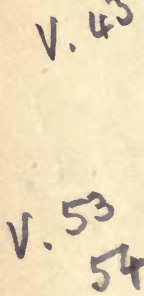

Uplands of N. America, wintering in S. America.

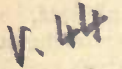

299. American Stint. Tringa minutilla, Vieillot. Two occurrences : Cornwall, 1853 ; Devon, 1869.

Outer tail-feathers grey ; legs and feet pale brown. Length 6 inches.

300. Pectoral Sandpiper. Tringa maculata, Vieillot. The most frequent of wanderers from America.

- Above brownish black, each feather edged with reddish brown; rump and upper tail-coverts blackish; wing-coverts blackish grey, margined with light grey. Central tail-feathers uniform blackish, and about a quarter of an inch longer than the next ones. Legs and feet yellowish green. Length $8 \frac{1}{2}$ inches.

- 301. Bonaparte's Sandpiper. Tringa fuscicollis, Vieillot. A much rarer straggler than the above.

Rump and upper tail-coverts white, streaked with blackish brown ; legs and feet brown; bill straight and as short as head. Length $7 \frac{1}{2}$ inches.

302. Buff-Breasted Sandpiper. Tryngites rufescens (Vieillot). Rare straggler.

Bill shorter than head, slightly curved down.

General colour dark buff; under surface of wings buff, marbled with black and white; axillaries white; tail graduated, two centre feathers black, the rest buff, marbled with black and white; legs buff. Length 7 inches.

303. RuFF. Machetes pugnax (Linnæus). Formerly bred in E. of England, now chiefly on migration from spring to autumn.

Rufr, male ; ReEve, female.

Axillaries white, no white on primaries, secondaries, or central upper tail-coverts; outside tail-feathers mottled; bill straight, as long as head.

Male in spring. With a ruff of various shades from black to pure white and chestnut.

Female, and male in winter. Without ruff. Legs yellowish brown. Length : male $12 \frac{1}{2}$ inches, female $10 \frac{1}{2}$.

304. Bartram's Sandpiper. Bartramia longicauda (Bechstein). Rare straggler.

Much resembles Reeve, but has quills and tail-feathers barred with black. Wings not reaching to end of tail.

Axillaries white, barred with dark brown; under wing-coverts barred with black and white; tail rather long and graduated. Length 12 inches.

305. Green SANDPIPER. Totanus ochropus (Linnæus). Occurs during all months; most rarely in June, most commonly in August. Not yet detected breeding in the British Islands ; on Continent lays in old nests on trees.

Bill straight, longer than head, as in next seven species. 
Above greenish brown, with minute white spots; below white; mump and outer tail-feathers on each side white; axillaries brownish black, with narrow white bars; legs dark green. Length $9 \frac{1}{2}$ inches.

306. Solitary Sandpiper. Totanus solitarius (Wilson). Three occurrences : Clyde ('Ibis,' 1870); Cornwall, 1882 and 1885.

Much as last, but no white on rump; axillaries evenly barred with brown and white, no traces of bars on primaries. Length $9 \frac{1}{2}$ inches.

307. Wood-Sandpiper. Totanus glareola (J. F. Gmelin). On passage in spring and autumn; once found breeding in Northumberland by J. Hancock in 1853 .

Above greenish brown, each feather margined with buffy-white spots; upper tail-coverts white; axillaries white, sometimes with a few dusky bars ; legs pale olive, $1 \frac{1}{2}$ inches long. Length $7 \frac{1}{2}$ inches.

308. Yellowshaxk. Totanus flavipes (J. F. Gmelin). Two occurrences: Notts and Cornwall.

Axillaries white, slightly marked with brown; legs bright yellow, about 2 inches long. Length $10 \frac{3}{4}$ inches.

309. Common Sandpiper. Totanus hypoleucus (Linnæus). Spring to autumn.

Above greenish brown; axillaries white; secondaries brown, with white bases and tips. Length $7 \frac{1}{2}$ inches.

310. Redshank. Totanus calidris (Linnæus). Resident.

Secondaries, axillaries, and upper tail-coverts white; legs and feet red in adults, yellowish in young. Length 10-11 inches.

311. Duskr Redshank. Totanus fuscus (Linnæus). On passage in spring and autumn.

Larger than last; secondaries white, barred with grey; upper tailcoverts white, barred with blackish brown; legs red. Length 12 inches.

312. Greenshank. Totanus canescens (J. F. Gmelin). Breeds in N. Scotland; found elsewhere in autumn and in spring; seldom in winter, except in West of Ireland.

Secondaries uniform grey; bill black, longer than head, and slightly turned upwards; legs olive-green.

In breeding-season has blackish marks on back and black spots on flanks, most developed in the female. Length 13-14 inches.

313. Bar-tailed Godwit. Limosa lapponica (Linnæus). Autumn o to spring.

Bill as in next species very long.

Rump nearly white; axillaries barred with black and white; tail barred in spring and in young birds; adults in winter have tail ashgrey, marbled at the base, long tail-coverts barred.

N. America, wintering in S. America.

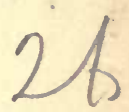

N. America, wintering in S. America.
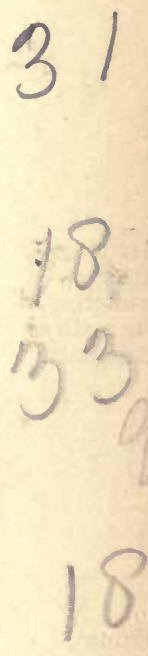
Female Godwits much larger than males.

In summer. Below pale red, darker in male.

In winter. Below white, above greyish brown; feathers with dark shaft-streaks. Length 15-16 inches.

314. Black-tatled Godwit. Limosa belgica (J. F. Gmelin). Formerly bred in the east of England; now only occurs on migration.

Larger than last; upper tail-coverts white; tail black, with white base; white bar across wing; axillaries white, but sometimes barred with brown.

In summer. Breast reddish, belly white, barred with blackish brown.

In winter. Ashy brown above, below greyish white. Length 16-20 inches.

\section{CuRlew. Numenius arquata (Linnæus). Resident.}

Bill as in next two species, very long and curved downwards.

Crown pale brown, regularly streaked with dark brown; axillaries white, barred with dark brown ; rump paler than back. Length 21-26 inches.

316. Whimbrei, or "MaY-Bird." Inumenius phcoopus (Linnæus). On passage in spring and autumn; a few breed on some of the islands in the north of Scotland.

Crown dark brown, with pale streak along the top; in some young birds this streak is almost obsolete and the brown on head has a glossy sheen; axillaries white, barred more or less with brown. Length 1618 inches.

Arctic V 59 317. Eskimo Whimbred. Numenius borealis (J. R. Forster). Rare America, $\sqrt{ }$ straggler.

Smaller than last, pale stripe on crown, no white on rump; axillaries chestnut, barred with brown; back of legs covered with hexagonal reticulations. Length 14 inches.

\section{Order G A V I Æ.}

\section{Family LAR I D 屃.}

\section{Subfamily STERNIN æ. Legs and feet small and weak; bill as long as or longer than head.}

Europe, N. Africa, America.

S. \& C. Europe, Africa, W. Asia, Ceylon, N. Zealand.

318. Black Terv. Hydrochelidon nigra (Linnæus). Formerly bred in the east of England; now only on migration.

Head, neck, breast, ard belly black; vent and under tail-coverts white; under wing-coverts pale grey; rest of plumage slate-grey; bill black; legs reddish brown. Length 10 inches.

Autumn. Forehead, throat, and nape white; below barred with white.

319. WhIme-wINGed BLACK TeRN. Hydrochelidon leucoptera (Schinz). Irregular visitor on migration.

Head, neck, underparts, and under wing-coverts black; vent, tail, and it tail-coverts white; bill dark red; legs scarlet. Length $9 \frac{1}{2}$ inches. 
320. Whiskered Terv. Hydrochelidon hybrida (Pallas). Very rare. s. Europe,

Forehead, crown, and nape black; chin and sides of neck white; belly very dark brown, almost black; rest of plumage grey or white; under wing-coverts white; bill dark red; legs vermilion. Length $11 \frac{1}{2}$ inches.

321. Gull-billed Tern. Sterna anglica, Montagu. Rare wanderer; only to England.

f Head and bill black; lower mandible slightly angulated or "Gullbilled"; tail bluish grey. Length 13-14 inches. only.

322. Caspian Tern. Sterna caspia, Pallas. Rare visitor, to England

The largest of the Terns.

Head black; tail white; bill red, dark at tip; legs black. Length $19-21$ inches.

323. Sandwich Tern. Sterna cantiaca, J. F. Gmelin. Spring to 6 autumn. Breeds as far north as the mouth of the Findhorn.

The next in size of the British Terns.

Head black; tail white; bill black, with yellow tip; legs black. Length 15 inches.

7 324. Roseate Tern. Sterna dougalli, Montagu. Spring to autumn. Rarely nests.

A very slender Tern.

Underparts tinged with roseate; primaries with white inner margins to the tips; tail deeply forked, about 9 inches long, outer feathers 6 inches longer than central; bill black, red at base; legs vermilion. Length $15-17$ inches.

325. Arctic Tern. Sterna macrura, Naumann. Spring to autumn. Breeds much further north than next species, and as far south as Humber in Great Britain and Kerry in Ireland.

Crown black; below as grey as the back. First primary with the grey stripe along the shaft of the inner web no broader than the outer web; bill and legs coral-red; legs shorter than in next. Length 15 inches.

326. Common Terv. Sterna fluviatilis, Naumann. Spring to autumn. Has bred as far north as Sutherland.

Crown black, below white.

First primary with the grey stripe along the shaft of the inner web twice as broad as the outer web; bill and legs coral-red; bill blackish at tip. Length 14 inches.

327. Little Tern. Sterna minuta, Linnæus. Spring to autumn. Has bred as far north as Aberdeenshire.

Crown black; forehead white; rump and tail white; bill yellow; legs bright orange. Length $8 \frac{1}{2}$ iuches.

Sinallest British Tern.

Africa,

Europe, Asia,

Africa, America.

Europe, Asia Australia, $\mathrm{N}$. America Mexico.

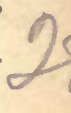


Tropical ; Ascension Island.

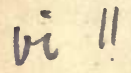

328. Sootr TenN. Sterna fuliginosa, J. F. Gmelin. Throe occurrences, 1869, 1882, 1885, all in England.

Crown and sides of head black; forehead white; above nearly black, below white; tail much forked; feet webbed to ends of toes. Length 16 inches.

Tropical.

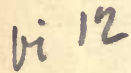

329. Lesser Sooty Tern. Sterna anoestheta, Scopoli. One record: mouth of Thames, 1875.

Smaller than preceding, paler above ; nape white; web between outer and middle toe not reaching to the claw of the middle toe. Length 14 inches.

Tropical.

330. Noddy TERN. Anous stolidus (Linnæus). Two records : Wexford, 1830.

General colour dark brown; forehead and crown grey; throat leadgrey; tail long and graduated. Length $14 \frac{1}{2}$ inches.

Subfamily LARIN $\mathrm{E}$. Legs and feet large and strong; bill shorter than head.

Arctic America to Peru in winter.

331. Sabine's Gull. Xema sabinii (Joseph Sabine). Irregular straggler. Young not infrequent; adults very rare.

Tail forked.

Aduit, spring. Head dark grey, with black line underneath. Length 13 inches.

Arctic.

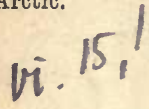

332. Wedge-tailed Gull. Rhodostethia rosea, Macgillivray. One record : Yorkshire.

Tail long and graduated. Head rose-colour; black collar round middle of neck; bill black; legs and feet vermilion. Length 14 inches.

Eggs unknown.

N. Russia to

333. Litrue Gull.

Larus minutus, Pallas. Autumn to spring, Mediterranean sometimes in numbers.

in winter.

Spring. Head black.

Winter. Head white, with a few dusky spots.

Young. Head brownish, marked with black and grey.

Smallest Gull, length of wing under $9 \frac{1}{2}$ inches. Length 10-11 inches.

Arctic

America, wintering in Florida and California.

vi. 17

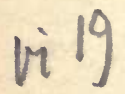

334. Bonaparte's Gull. Larus philadelphia, Ord. Rare straggler.

Head greyish black; bill black, -rather slen'der; legs red; outer web of first primary black, white or pale grey margins to inner webs of two outer primaries, broad black ends to first six. Length 14-15 inches.

335. BROwn-Headed GULL. Larus ridibundus, Linnæus. Resident.

Head sooty brown from about March 1st to August 1st.

Winter. Head white, with grey patch behind eye.

Young. Marked above with brown, and, as in all black-headed Gulls, has blackish bar at end of tail.

Primaries white, with black tips, edged on the inner web with black and usually on the outer web. Length 15-16 inches. 
336. Mediterranean Black-Headed Gulu *. Lamus melanocephalus, Natterer. Recorded from Yarmouth, Dec. 1886.

E. Mediterranean.

Bill stouter than last.

In summer. Head jet-black.

Adults. Primaries white, except the first, which has the outer web margined with black.

Young. Outer webs and shafts of first five primaries dark brown, outside of inner web of third primary white. Length 15 inches.

337. Great Black-headed Guld. Larus ichthyaëtus, Pallas. One occurrence : Exmouth, June 1859.

Bill orange-yellow, crossed near end with black bar; head, throat, and nape black; small white mark above and below eye. Length 29 inches.

338. Common Golt. Larus canus, Linnæus. Resident; not known z to breed south of the Solway in Great Britain, but nests in West of Ireland.

In spring. Head and neck white; mantle pale grey; bill and legs greenish yellow; former yellow at point.

In winter. Head and neck streaked and spotted with brown; legs pale brown.

Young. Head, neck, and underparts white, mottled with light brown; tail with black band at end. Primaries black or dark brown, with white spots at the end or next the end. Length 18 inches.

339. Herring-Gull. Larus argentatus, J. F. Gmelin. Resident.

Head and neck white; mantle pale grey; legs and feet flesh-colour.

Young. Feathers above brown, with pale edges; tail barred with brown ; underparts white, streaked with brown. Length 22-24 inches.

340. Lesser Black-backed GulL. Larus fuscus, Linnæus. Resident. 4 Head and neck white; mantle slaty black; legs and feet yellow; primaries nearly uniform dark brown.

Young. Like last. Length 21-23 inches.

341. Great Black-backed Gold. Larus marinus, Linnæus. Resident.

5 Resembles last, but larger. Legs and feet flesh-colour; distinct wedge on third and fourth primaries.

Young. Like last. Length 26-33 inches.

342. Giadcous Guld. Larus glaucus, O. Fabricius. Winter visitor. Arctic.

6 Adult. Entirely white, except grey mantle; head and neck streaked with ash-grey in winter.

Young. Dull white, mottled with pale brown; primaries grevish white; for a short time before assuming adult plumage the mantle is entirely white. Length 26-33 inches.

* Eggs obtained in the S.W. of Spain, and stated to belong to this species, appear to have been those of the Gull-billed Tern, Sterna anglica.

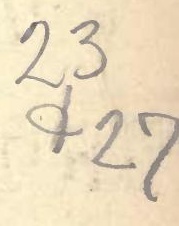


Arctic. of 343. ICELand Gulx. Larus leucopterus, Faber. Winter straggler.

ii 28 Like last, but smaller; wings relatively much longer, being nearly as long as those of last.

Young. As in Glaucous Gull. Length 22 inches.

344. Kтттішакe. Rissa tridactyla (Linnæus). Partially resident. Nests on rocks.

Hind toe absent or rudimentary.

In summer. Head, neck, and tail pure white; bill greenish yellow.

In winter. Head and neck slate-grey.

Young. Bill black; brown feathers on back; tail with black band at end. Length 15 inches.

Arctic.

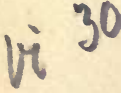

345. Ivory Gulx. Pagophila eburnea (Phipps). Rare, in winter.

Entirely white; legs black; tail rather long and slightly graduated; hind toe connected with leg by a web.

Young. Black spots on wings, tips of quills, and tail-feathers; still younger birds have black spots also on back. Length 16-18 inches.

\section{Subfamily STERCORARIINA. ROBBER-GULLS.}

Base of upper mandible covered with a cere or skin, and hooked at the point.

Sub-arctic. 346. Great Skda. Stercorarius catarrhactes (Linnæus). Breeds in Shetlands, where it is now protected.

General colour above dark brown; below lighter brown; axillaries dark brown; primaries blackish brown, bases white, forming a wellmarked band. Tail dark brown, white at the base, but this is hidden by the coverts; two centre feathers very slightly longer than the others. Length 24-25 inches, leg $2 \frac{3}{4}-3 \frac{1}{4}$.

Arctic, to

347. Twist-tailed or Pomatorhine SkUa. Stercorarius pomato$\mathrm{N}$. Australia in rhinus (Temminck). Autumn to spring.

winter.

Two forms or races are found, both dark brown above. The dark form as dark below as above; the light form white below, barred on flanks and tail-coverts with dark brown, white on the throat, tinged with golden yellow, and sometimes extending round nape.

Centre tail-feathers 4 inches longer than the others, and twisted upwards.

Young. Above dark brown; below paler, with buff margins to the feathers; tail brown, two centre feathers only very slightly longer than the others. Length 21 inches, leg 2.

$82^{\circ} \mathrm{N}$., to

N. Zealand in winter.

348. Richardson's. SkUa. Stercorarius crepidatus (J. F. Gmelin). Breeds on one or two places on the mainland and on some of the islands of N. of Scotland.

Two forms or races are found. 
Dark race. Adult uniform sooty brown, to which the name Richardson's is strictly applied ; but the name Arctic, also employed, is a misnomer, as this bird breeds and also migrates further south than any of the other northern Skuas.

Light race. Adult nearly as those of next species, but two centre tailfeathers only 3 inches longer than the others. Legs black.

Young. Sooty brown; paler below; centre tail-feathers little longer than the others.

All primaries with white shafts.

Length, including centre tail-feathers, about 20 inches.

349. Long-tatled or Befrox's Skda. Stercorarius parcasiticus (Linnæus). Irregularly, autumu to spring.

Adult. Crown black; above lrownish grey; below white; sides of neck white, tinged with yellow; legs slate-grey. Two central tailfeathers about 9 inches longer than the others.

Young. Sooty brown; flanks and tail-coverts with buff margins; centre tail-feathers little longer than the others.

First two primaries with white shafts, but it is said that the nostrils of Buffon's Skua are nearer the frontal feathers than the tip of the billin Richardson's Skua the contrary being the case.

Length, including central tail-feathers, $22 \frac{1}{2}$ inches.

\section{Order P YGOPODES. Family ALCID压.}

Great Aur. Alca impennis, Linnæus. Extinct: last British specimen, 1834 ; last foreign record, 1844.

630. Razorbill. Alca torda, Linnæus. Resident.

6 Bill black, straight, large, much decurved towards point, with curved white line across centre on each side; upper mandible hooked, with three grooves across.

In summer. Above black, with green gloss; secondaries tipped with white, forming a band; narrow white streak from base of upper mandible to eye; below white, but chin and throat blackish.

In winter. Green gloss above nearly absent; chin, throat, and sides of bead white; in young birds bill less developed. Length 17 inches.

\section{Common Guillemot. Uria troile (Linnæus). Resident.}

Bill blackish, straight and pointed.

In summer. Head, neck, and upper surface dark brown; below white.

In winter. Throat and sides of head white. Length 18 inches.

The Ringed Guillemot is a race or variety, with a white ring round the eye and a white line running backwards therefrom.

Arctic, to $40^{\circ} \mathrm{N}$. in winter.
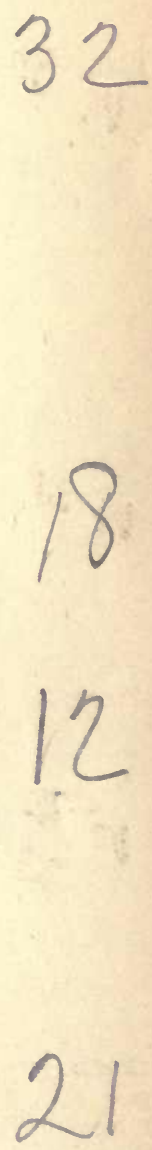
Arctic. 9 352. THICK-BILIED or BRÜNNICH's GUILLEMot. Uria bruennichi, E. Sabine. Recorded on sumewhat slight evidence.

Larger and darker than last, and with shorter and stouter bill, base of the upper mandible whitish.

353. Black Guillemot. Uria grylle (Linnæus). Resident : breeds on Isle of Man, Scotch and Irish coasts.

Legs, feet, and inside of mouth vermilion.

In summer. Black, middle and great wing-coverts, basal half of inner web of primaries, under wing-coverts, and axillaries white ; wing-coverts with hidden black bases.

In winter. Head and nape white, speckled with black; back, scapulars, and upper tail-coverts black, barred with white; rump and underparts white ; wings and tail black; bill black, red at base. Length 14 inches.

Arctic. 354. Litrice AđK. Mergulus alle (Linnæus). In winter.

Bill black, shorter than head, thick, broader than high at base.

i $4^{2}$ In summer. Above black, except ends of secondaries and sides of scapulars, which are margined with white; small white spot over eye; chin, throat, and fore neck black; rest below white.

In winter. The same; but chin, throat, and fore neck are white. Length $8 \frac{1}{2}$ inches.

355. Puffin. Fratercula arctica (Linnæus). Resident.

Bill shorter than head, higher than long; both mandibles arched (and in summer grooved across with orange).

Above black; forehead and crown greyish brown; black ring round white throat; below white; axillaries brown; legs orange.

In winter the bill is smaller and without brighter colour, the base of the bill being shed in autunn. Length 12 inches.

\section{OLYMBID无.}

(Females smaller than males.)

356. Grent Northern Diver. Colymbus glacialis, Linnæus. Chiefly autumn to spring; occurs in the Shetlands in summer.

Adult : spring. Head and neck black, with purple gloss; a band of white stripes on throat, below which is another band of white stripes; bill black; iris red.

Winter. Above uniform blackish brown, more or less spotted with white; below white. Length 30-33 inches.

Arctic, 357. White-BiLled Northern Diver. Colymbus adamsi, G. R. Gray. Scarce or overlooked straggler.

Resembles Great Northern Diver, but is larger. Adults have yellowishwhite bill, upper mandible slightly curved up, and the white spots on back larger. 
6 358. Brack-throated Diver. Colymbus arcticus, Linnæus. Breeds locally in N. of Scotland, migrating southward in winter.

Adult : spring. Chin and throat black, with a purple gloss, divided by a patch of white with black lines; iris red.

Winter. Like last, but smaller. Length 25 inches.

359. Red-throated Diver. Colymbus septentrionalis, Linnæus. Breeds in N. of Scotland and Ireland.

Adult : spring. Throat grey, with lower part chestnut-red.

Winter. Above ashy grey, speckled and spotted with white, most so in the young; underparts white. Length 21-23 inches.

PODICIPEDID无. Feet with lobes; no true tail.

360. Great Crested Grebe. Podicipes cristatus (Linnæus). Resident.

Male: summer. Crown and tufts black; tippet round face chestnut, with black edges.

Female. Rather smaller; crest and tippet not so much developed.

In winter these ornaments are scarcely present in the adult male, less so in the female, and absent in the young; all have white eye-stripe. Length $20-24$ inches.

361. Red-NeCKed GreBe. Podicipes griseigena (Boddaert). Autumn to spring.

In summer. Crown, nape, back of neck black; chin and throat grey; neck in front chestnut-red; no tippet; bill black, base of bill yellow.

In winter. Neck in front grey; no eye-stripe. Length $16 \frac{1}{2}$ inches.

362. Lesser Crested or Slavonian Grebe. Podicipes auritus (Linnæus). Autumn to spring; not known to breed in British Islands.

Bill straight.

In summer. With tuft of lengthened chestnut feathers on each side of head from bill to nape; crown, forehead, chin, and ruff or tippet black; neck and flanks chestnut.

In winter. As in last. Length 13 inches.

363. Black-Necked or Eared Grebe. Podicipes nigricollis, C. L. Brehm. Autumn to spring.

Bill slightly curved upwards; inner four primaries white throughout.

In summer. Head and neck black, with a stripe from eye to nape of lengthened golden reddish feathers.

In winter. Resembles last in plumage, except the white on primaries, Length 12 inches. 
364. Dabchick, or Lithle Grebe. Podicipes fluviatilis (Tunstall). Resident: even breeds regularly in St. James's Park, arriving there in spring and leaving late in autumn.

In summer. Chin black; cheeks, sides, and front of neck reddish chestnut.

In winter. Chin white, the reddish chestnut of neck replaced by brown; iris brown. Length 8-9 inches.

\section{Order TUBINARES.}

\section{Family PROCELLARIID}

(Nostrils in a tube.)

365. Fulmar. Fulmarus glacialis (Linnæus). Resident, breeding on some islands of N. Scotland.

Head, neck, and underparts white; the rest grey.

A grey race occurs, with entire plumage ashy brown; back and wings darker. Length 19 inches.

W. Indies, Windward Islesp

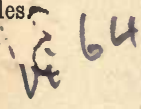

S. Pacific.
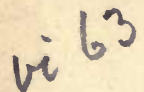

N. Atlantic, breeding in S. 0ceans.

N.\& S. Atlantic, Pacific, New Zealand.

in
366. Capped Petrel. in Norfolk, in 1850.

Head, crown, nape, back, and wings dark brown; rump, upper tailcoverts, forehead, and underparts white; tail graduated. Length 16 inches.

367. Collared Petrel. Estrelata torquata, John Macgillivray. Reported to have occurred on Welsh coast ('Ibis,' 1891, p. 411).

"Above light grey; face, cheeks, and chin white; crown, back of head, and neck sooty brown," but varies greatly in depth of colour. Length 12 inches.

368. Great Shearwater. Puffinus major, F. Faber. Irregular.

Head to below eye and nape dark brown, forming a distinct cap; back of neck whitish, feathers tipped with brown; cheeks, chin, throat, sides of neck, and breast white; centre of belly brownish ; back, wingcoverts, and rump dark brown, feathers tipped with light greyish; lower part of upper tail-coverts white; tail dark brown; axillaries white, tipped with light brown. Length 18-19 inches.

369. Sooty Shearwater. Puffinus griseus (J. F. Gmelin). Straggler. Underparts uniform brown. Length 17-18 inches.

370. Manx Shearwater. Puffinus anglorum (Temminck). Resident. Head, back, wings, and tail blackish brown; breast white; rest of underparts dark smoky grey; bill and legs bluish grey. Length 1314 inches, wing $9 \frac{1}{2}$. 
371. Dusky Shearwater. Puffinus obscumes (J. F. Gmelin). Two Atlantic, occurrences : Kerry Coast, 1853 ; Suffolk, 1858.

W. Indies.

Smaller than Manx Shearwater. Above black; underparts pure white; axillaries white. Length 11 inches.

372. White-faced or Frigate-Petrel. Pelagodroma marina N. Zealand, (Latham). Reported, once, from Lancashire Coast, Nov. 1890 (' Ibis,' S. Pacific. 1891, p. 602).

Forehead, face, line over eye and below pure white; above slatecolour; upper tail-coverts light; legs and feet black, webs yellow. Length 9 inches.

373. Bulwer's Petred. Bulweria columbina (Moquin-Tandon). One Canaries, occurrence : Yorkshire, 1837.

Uniform brownish black; tail long and wedge-shaped. Length Islands. $10 \frac{1}{4}$ inches.

374. Storm-Petrel. Procellaria pelagica, Linnæus. Resident.

Above slaty black; upper tail-coverts and sides of vent white; below darker; tail slightly rounded; legs and feet black. Length $5 \frac{1}{2}$ inches. Smallest web-footed bird.

375. Fork-tailed Petrex. Procellaria leucorrhoa, Vieillot. Resident, breeding in Hebrides, and Blasquets, Co. Kerry.

Slate-black abore, darker below; upper tail-coverts white; tail long, deeply forked. Length $7 \frac{1}{4}$ inches.

376. Long-Legged or Wilson's Petrel. Oceanites oceanicus (Kuhl). Atlantic, Scarce straggler.

Sooty black, darkest below; upper tail-coverts and sides of vent Island. Pacific, Kerguelen white; tail almost square; hind toe absent.

Legs $1 \frac{1}{2}$ inches long and slender, covered with large scales; toes black, with the centre of the webs yellow. Length $7 \frac{1}{2}$ inches. 
24 


\section{N D E X.}

[The figures denote the sequence-numbers, not pages.]

Accentors, 21, 22.

Alpine Accentor, 22.

"Swift, 129.

American Bittern, 192.

" Blue-winged Teal, 217.

" Goshawk, 164.

" Green-winged Teal, 216.

" Stint, 299.

"Wigeon, 220.

Aquatic Warbler, 35.

Aretic Skua, 348. Teru, 325.

Asiatic Golden Plover, 270.

Auks, 350, 354 .

Avocet, 282.

Baillon's Crake, 256.

Barn-Owl, 144.

Barred Warbler, 28.

" Woodpecker, 135.

Bar-tailed Godwit, 313.

Bartram's Saudpiper, 304.

Bean-Goose, 200.

Bearded Reedling, 51 .

Bee-eater, 140.

Bernacle Goose, 204.

Bewick's Swan, 208.

Bitterns, 190-192.

Blackbird, 6.

Blackcap, 26.

Black Duck, 233.

„ Grouse, 247.

" Guillemot, 353.

" Kite, 167 .

" Redstart, 17.

"Stork, 194.

" Tern, 318 .

", -headed Bunting, 98.

", -necked Grebe, 363.

" -tailed Godwit, 314.

-throated Diver, 358.

" " Thrush, 5.

:, "Wheatear, Western, 13.

, -winged Stilt, 283.

Blue-headed Yellow Wagtail, 112.
Blue-tailed Bee-eater, 140.

Bluethroat, Red-spotted, 18.

Blue Tit, 47.

Bonaparte's Gull, 334.

Brambling, 88 .

Sandpiper, 301.

Brandt's Siberian Bunting, 102.

Brent Goose, 203.

Broad-billed Sandpiper, 291.

Brown Owl, 147.

-headed Gull, 335.

Brünnich's Guillemot, 352 .

Buff-backed Heron, 186.

", -breasted Sandpiper, 302.

Buffel-headed Goldeneye, 227.

Buffon's Skua, 349.

Bullfineh, 94.

Bulwer's Petrel, 373.

Buntings, 98-108.

Bustards, 263-265.

Butcher-bird, 71.

Buzzards, 159, 160.

Calloo, 40.

Capercaillie, 246.

Capped Petrel, 366.

Carrion-Cruw, 66.

Caspian Plover, 275.

$$
\text { Tern, 322. }
$$

Cattle Heron, 186.

Chaffinch, 87 .

Chiffchaff, 40.

Chough, Red-billed, 60.

Cirl Bunting, 101.

Coal Tit, 48.

Collared Petrel, 367.

Common Buzzard, 159.

Coot, 260.
" Eider, 232.

," Guillemot, 351.

" Gull, 338.

" Heron, 182.

" Sandpiper, 309.

" Snipe, 288.

"Tern, 326 . 
Cormorant, 179.

Corn-Bunting, 99.

"-Crake, 254.

Oourser, Cream-coloured, 268.

Crakes, 25t-257.

Crane, 261.

Crean-coloured Courser, 268.

Creepers, 53, 54.

Crested Lark, 123.

" Tit, 50

Tit,

Crows, 66, 67.

Cuckoo, 142.

Curlew, 315 .

", -Sandpiper, 293.

Dabchick, 364 .

Dartford Warbler, 29.

Demoiselle Crane, 262.

Desert Wheatear, 12.

Dipper, 56.

Divers, 356-359.

Dotterel, 272.

Doves, 240-244.

Ducks, 209-235.

Dun-bird, 222.

Dunlin, 295 .

Dusky Redshank, 311.

" Shearwater, 371.

Eagles, 161-163.

Eagle-Owl, 152.

Eared Grebe, 363.

Eastern Turtle-Dove, 244.

Egret, Little, 185.

Egyptian Vulture, 155.

Eiders, 230-232.

Eskimo Whimbrel, 317.

Falcons, 169-177.

Fieldfare, 4.

Finches, 80-92.

Fire-crested Wren, 44.

Flamingo, 197.

Flycatchers, 74-76.

Fork-tailed Petrel, 375.

Frigate-Petrel, 372.

Fulmar, 365 .

Furze-Warbler, 29.

Gadwall, 212.

Gannet, 181.

Garden-Warbler, 25.

Garganey, 218.

Geese, 198-2005.

Glaucous Gull, 342.

Glossy Ibis, 196.

Goatsucker, 131.

Godwits, 313, 314.

Gold-crested Wren, 43.

Goldeneye, 226.

Golden Eagle, 162.

, Oriole, 57.
Golden Plover, 269.

Goldfincb, 82.

Goosander, 236.

Goshawk, 164.

Grasshopper Warbler, 36.

Great Auk, 350.

" Black-backed Gull, 341.

" Black-headed Gull, 337.

" Bustard, 263.

" Crested Grebe, 360.

" Grey Shrike, 69.

" Northern Diver, 356.

" Reed-Warbler, 31.

" Shearwater, 368.

" Skua, 346.

" Snipe, 287.

" Spotted Cuckoo, 143.

" , Woodpecker, 134.

" Tit, 46 .

", White Heron, 184.

Grebes, 360-364.

Green Cormorant, 180.

" Heron, 188.

" Plover, 278.

" Sandpiper, 305.

" Woodpecker, 136.

Greenfinch, 80.

Greenland Falcon, 169.

Greenshank, 312.

Grey Phalarope, 284.

" Plover, 271.

, Wagtail, 111.

", -headed Yellow Wagtail, 11\%.

", -lag Goose, 198.

Griffon Vulture, 154.

Grosbeak, Scarlet, 93.

Grouse, 247, 248.

Guillemots, 351-353.

Gulls, 331-345.

Gull-billed 'Tern, 321.

Gyr-Falcon, 171.

Harlequin Duck, 229.

Harriers, 156-158.

Hawfinch, 81.

Hawk-Owl, 150.

Hawks, 164, 165.

Hedge-Sparrow, 21.

Hen-Harrier, 157.

Herons, 182-189.

Herring-Gull, 339.

Hobby, 173.

Honey-Buzzard, 168.

Hooded Crow, 67.

Hoopoe, 141 .

Merganser, 238.

Houbara Bustard, Irudian, 265.

House-Sparrow, 85.

Ibis, Glossy, 196.

Iceland Falcon, 170.

Gull, 343

Indian Houbara Bustard, 265. 
Isabelline Nightjar, 133.

Ivory" Gull, 345 .

Jackdaw, 64 .

Jack Snipe, 289.

Jay, 62 .

Kentish Plover, 276.

Kestrel, 176.

Killdeer Plover, 277.

King Eider, 231.

Kingfisher, 138.

Kites, 166, 167.

Kittiwake, 344.

Knot, 294.

Land-Rail, 254.

Lapland Bunting, 108.

Lapwings, 278, 279.

Larks, 122-127.

Lesser Black-backed Gull, 340.

, Crested Grebe, 362.

" Grey Shrike, 70 .

, Kestrel, 177.

" Redpoll, 91.

" Sooty Tern, 329.

" Spotted Woodpecker, 135.

', White-fronted Goose, 199.

, Whitethroat, 24.

Linnet, 89.

Little Auk, 354.

” Bittern, 190.

" Bunting, 105.

” Bustard, 264.

” Crake, 257.

" Egret, 185.

," Grebe, 364.

, Gull, 333 .

, Owl. 153.

” Ringed Plover, 274.

, Stint, 298.

" Tern, 327.

Long-eared Owl, 145.

" -legged Petrel, 376.

” -tailed Duck, 228.

" , $\quad$ Skua, 349.

, " $\quad$ Tit, 45 .

Magpie, 63.

Mallard, 211.

Manx Shearwater, 370.

Marsh-Harrier, 156.

"-Tit, 49.

, -Warbler, 33.

Martin, 78.

May-bird, 316.

Meadow-Pipit, 116.

Mealy Redpoll, 90.

Mediterranean Black-headed Gull, 336.

Mergansers, 237, 238.

Merlin, 174.

Mistle-Thrush, 1.
Montagu's Hamer, 158.

Moorhen, 259.

Mountain-Linnet, 92

Mute Swan, 206.

Night-Heron, 189.

Nightingale, 20 .

Nightjar, 131.

Noddy Tern, 330.

Nutcracker, 61.

Nuthatch, 52.

Oriole, Golden, 57.

Orphean Warbler, Western, 27.

Ortolan, 103.

Osprey, 178.

Ouzel, Ring, 7.

Water, 56 .

Owls, 144-153.

Oyster-catcher, 280.

Partridge, 251.

Pectoral Sandpiper, 300.

Peewit, 278.

Peregrine Falcon, 172.

Petrels, 366-376.

Phalaropes, 284, 285.

Pheasant, 250.

Pied Flycatcher, 75 .

,Wagtail, 110.

Pine-Grosbeak, 95.

Pink-footed -Goose, 201.

Pintail, 214.

Pipits, 115-121.

Plovers, 269-278.

Pochards, 221, 222.

Polish Swan, 206.

Pomatorhine Skua, 347.

Pratincole, 266.

Ptarmigan, 249.

Puffin, 355.

Purple Heron, 183.

„ Sandpiper, 296.

Quail, 253.

Raven, 65.

Razorbill, 350.

Red Grouse, 248.

, Kite, 166.

",-backed Shrike, 71 .

-billed Chough, 60.

-breasted Flycatcher, 76.

". , Goose, 205.

" " Mergancer, 237.

" Snipe, 290.

-crested Pochard, 221.

-footed Falcon, 175.

-legged Partridge, 252.

-necked Grebe, 361.

, Phalarope, 285. -spotted Bluethroat, 18.

-throated Diver, 359. 
Red-throated Pipit, 117.

Redpolls, 90, 91 .

Redshank, 310, 311.

Redstart, 16.

Redwing, 3.

Reed-Bunting, 106. " -Warblers, 31, 32.

Reeve, 303 .

Richard's Pipit, 121.

Richardson's Skua, 348.

Ring-Dove, 240.

"-Ouzel, 7.

Ringed Guillemot, 351.

Robin, 19.

Rock-Dove, 242.

, -Pipit, 118.

" -Thrush, 9.

Roller, 139.

Rook, 68.

Roseate Tern, 324.

Rose-coloured Starling, 59.

Rough-legged Buzzard, 160.

Ruddy Sheld-drake, 210.

Ruff, 303.

Rufous Warbler, Western, 30. -naped Nightjar, 132.

Rustic Bunting, 104.

Sabine's Gull, 331 .

Sanderling, 292.

Sand-Grouse, Three-toed, 245.

Sand-Martin, 79.

Sandpipers, 291-309.

Sandwich Tern, 323.

Savi's Warbler, 37.

Scarlet Grosbeak, 93.

Scaup, 225.

Scops Owl, 151.

Scoters, 233-235.

Sea-Eagle, 163.

Sedge-Warbler, 34.

Serin Finch, 84 .

Shag, 180.

Shearwaters, 368-371.

Sheld-drakes, 209, 210.

Shore-Lark, 127.

Short-eared Owl, 146. ," -toed Lark, 125.

Shoveler, 213.

Shrikes, 69-72.

Siberian Bunting, 102.

Siskin, 83.

Thrush, $8 a$.

Skuas, 346-349.

Sky-Lark, 122.

Slavonian Grebe, 362.

Smew, 239.

Snipe, 287-290.

Snow-Bunting, 107.

, -Goose, 202.

Snowy Owl, 149.

Sociable Lapwing, 279.
Solitary Sandpiper, 306.

"Snipe, 287.

Song-Thrush, 2.

Sooty Shearwater, 369.

„ Tern, 328.

Sparrow, Hedge, 21.

" House, 85.

" -Hawk, 165.

Spine-tailed Swift, 130.

Spoonbill, White, 195.

Spotted Crake, 255.

" Eagle, 161.

" Flycatcher, 74.

Squacco Heron, 187.

Starling, 58.

Steller's Eider, 230.

Stilt, 283.

Stints, 297-299.

Stock-Dove, 241.

Stonechat, 15.

Stone-Curlew, 267.

Storks, 193, 194.

Storm-Petrel, 374.

Summer Teal, 218.

Surf-Scoter, 235.

Swallow, 77.

Swans, 206-208.

Swift, 128.

Tawny Owl, 147.

Teal, 215. Pipit, 120.

Temminck's Stint, 297.

Tengmalm's Owl, 148.

Terns, 318-330.

Thick-billed Guillemot, 352.

Thick-knee, 267.

Three-toed Sand-Grouse, 245.

Thrushes, 1-20.

Tits, 45-50.

Tree-creeper, 53.

" -Pipit, 115.

"-Sparrow, 86.

Tufted Duck, 224.

Turnstone, 281.

Turtle-Dove, 243.

Twist-tailed Skua, 347.

Twite, 92.

Two-barred Crossbill, 97.

Velvet Scoter, 234.

Vulturcs, 154, 155.

Wagtails, 109-114.

Wall-creeper, 54 .

Warblers, 23-42.

Waterhen, 259.

Water-Ouzel, 56.

, -Pipit, 119.

" -Rail, 258.

Waxwing, 73.

Wedge-tailed Gull, 332.

Western Black-throated Wheatear, 13. 
Wheatears, 10-13.

Whimbrel, 316, 317.

Whinchat, 14.

Whiskered Tern, 320.

White Heron, Great, 184.

" Owl, 144.

" Spoonbill, 195.

" Stork, 193.

", Wagtail, 109.

" -billed Northern Diver, 357.

" -eyed Pochard, 223.

", -faced Petrel, 372.

," -fronted Goose, 199.

," -tailed Eagle, 163.

", -winged Black Tern, 319 .

", $\quad$ Lark, 126.

White's Thrush, 8.

Whitethroat, 23.

Whooper Swan, 207.
Wigeon, 219.

Wild Duck, 211.

Willow-Warbler, 41.

Wilson's Petrel, 376.

Woodchat Shrike, 72.

Woodcock, 286.

Wood-Lark, 124.

Woodpeckers, 134-136.

Wood-Pigeon, 240.

, -Sandpiper, 307.

, -Warbler, 42.

Wren, 55.

Wryneck, 137.

Yellow Hammer, 100.

„ Tree-Warbler, 38.

" Wagtail, 114.

, -browed Warbler, 39.

Yellowshank, 308. 




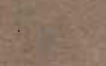

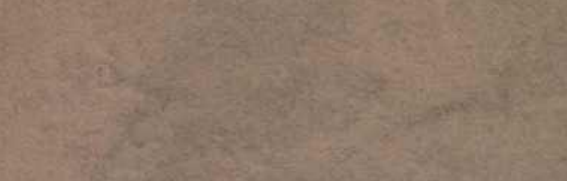

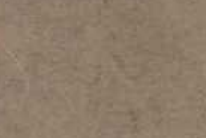 \\ Stist

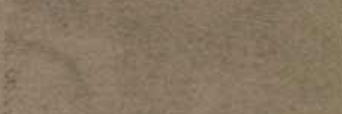

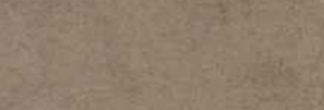 \\ $4=3,509$

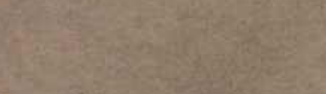

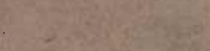 \\ stils 5 s:

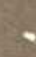 \\ $x+\frac{1}{x+2}=$

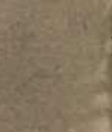

$\therefore$

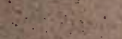

$\frac{6}{4}$

(4)

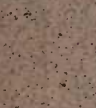

$\therefore>$

$\therefore \therefore$

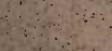

$\therefore$

$\therefore \%$

$+$

$\frac{4}{4}$

$\therefore$

$\frac{2}{2}+2$

4

9.63:3

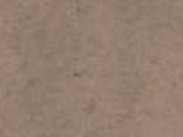

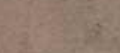

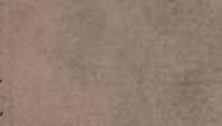

50 intis
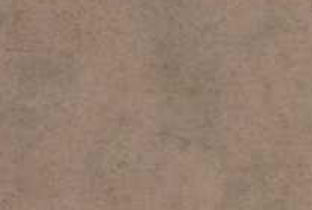

ats

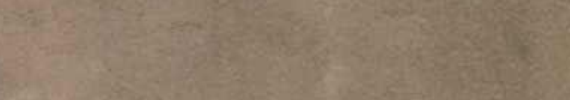

